\title{
Wind Turbine Model and Maximum Power Tracking Strategy
}

\author{
Hengameh Kojooyan Jafari and Ahmed Radan \\ Islamic Azad University-Islamshahr Branch, \\ K.N. University of Technology \\ Iran
}

\section{Introduction}

Today doubly fed induction generators (DFIG) are used for modern wind turbines to deliver electrical power to the grid. A speed variation of $\pm 30 \%$ around synchronous speed can be obtained by the use of power converter of $\pm 30 \%$ of nominal power. Furthermore, it is possible to control active and reactive power, which gives a better performance, and the power electronics enables the wind turbine to act as a more dynamic power source to the grid. The DFIG does not need either a soft starter or a reactive power compensator. This system is naturally a little bit more expensive compared to the classical systems; however, it is possible to save money on the safety margin of gear and reactive power compensation units, and it is also possible to capture more energy from the wind (Blaabjerg \& Chen, 2006). A wind turbine with maximum power tracking is a very suitable power source to the grid. This new model, as a dynamic power source to the grid, comprises a maximum power tracking wind turbine, a doubly fed induction machine with winding configuration, external rotor resistance and external rotor source which has a variable phase and amplitude. In this chapter its simulation, effects of important parameters, design of a special kind of voltage controller and a new combined controller for it and comparison of these controllers are presented.

\section{Key words}

Doubly fed machine, Wind turbine, Voltage controller, Combined controller

\section{Maximum power tracking wind turbine}

Maximum power tracking wind turbine can deliver maximum power to the grid in low and high wind speeds.

Turbine torque via wind is inferred from following equations (1) to (3):

$$
\begin{gathered}
\lambda=\frac{\omega_{M} \times R}{V_{\text {wind }}} \\
P_{M}=\frac{1}{2} \rho \pi R^{5} C_{P} \frac{\omega_{M}{ }^{3}}{\lambda^{3}}
\end{gathered}
$$




$$
T_{M}=\frac{P_{M}}{\omega_{M}}=\frac{1}{2} \rho \pi R^{5} C_{P} \frac{\omega_{M}^{2}}{\lambda^{3}}
$$

Where, $V_{\text {wind }}$, the wind speed, is measured in $\mathrm{m} / \mathrm{s}, \mathrm{R}$, the blade radius is measured per $\mathrm{m}, \rho$ $\left(1.24 \mathrm{~kg} / \mathrm{m}^{3}[4]\right)$, air density is measured in $\mathrm{kg} / \mathrm{m}^{3}, \omega_{\mathrm{M}}$, turbine mechanical speed, is measured in rad/sec, $\lambda$ is tip-speed ratio (TSR) and $C_{p}$ is power coefficient, i.e. ratio of turbine power (power extracted) to wind power (power available) and it depends on aerodynamics specifications of blades (Hoseinpur, 2001), (Burter et al., 2001).

$C_{p}$ is function of $\lambda$ (Burter et al., 2001):

$$
C_{P}=0.22\left[116\left(\frac{1}{\lambda+0.08 \beta}-\frac{0.035}{\beta^{3}+1}\right)-0.4 \beta-5\right] e^{-12.5\left(\frac{1}{\lambda+0.08 \beta}-\frac{0.035}{\beta^{3}+1}\right)}
$$

Where $\beta$ is blade pitch angle.

Simulation of turbine for two typical wind speed, 4 and $5 \mathrm{~m} / \mathrm{s}$ that are in valid range of speed between low-shutdown speed and high stopped speed, has been performed for improved turbine parameters according to table1 (Hoseinpur, 2001):

\begin{tabular}{|c|c|}
\hline Nominal power & $15 \mathrm{kw}$ \\
\hline Blade radius & $5.5 \mathrm{~m}$ \\
\hline Blade pitch angle & $0^{\circ}$ \\
\hline
\end{tabular}

Table 1. Turbine parameters

In a fixed wind speed, maximum power of turbine can be achieved from $\mathrm{C}_{\mathrm{Pmax}}$ function considering improved $\lambda$. Improved parameters from equation (8) are presented in table2 (Hoseinpur, 2001).

\begin{tabular}{|c|c|}
\hline$\lambda_{\mathrm{i}}$ or Improved TSR & $\mathrm{C}_{\mathrm{pmax}}$ or Maximum power coefficient \\
\hline 8.636 & 0.48 \\
\hline
\end{tabular}

Table 2. Improved parameters of turbine

Then, by using equations (1), (2), maximum turbine power is calculated.

\section{Doubly fed induction machine}

Most of wind turbine generators are induction generators that are very reliable and costs of them are low (Ehernberg et al., 2001).

Induction generators are not complicated. These generators can give active power to grid however they take reactive power from it.

In these generators at $50 \mathrm{HZ}$ frequency, the angular frequency is usually among $1200 \mathrm{rpm}$ to 1800rpm (relative to number of poles) and gear ratio is among 30 to 50 (Burter et al., 2001).

Recently use of doubly-fed induction generators in wind turbines has become more common; however, they are more complicated than ordinary induction machines.

Voltage equations of an induction generator in $\mathrm{ABC}$ system are given by equation (5) (Krause, 1986): 


$$
V_{S, r}=R_{S, r} \bullet i_{S, r}+\frac{d}{d t}\left(L \bullet i_{S, r}\right)
$$

And n, the ratio of equivalent stator turns to equivalent rotor turns is unit (Krause, 1986):

$$
\begin{aligned}
& n=1 \\
& L_{m s}=\frac{2}{3} L_{m} \\
& L_{m s}=L_{m r}
\end{aligned}
$$

And electromagnetic torque is according to equation (7) (Krause, 1986):

$$
T_{e}=\left(i_{a b c S}\right)^{T} \frac{d}{d \theta_{m}}\left(L_{s r}^{\prime}\right) \bullet i_{a b c r}^{\prime}
$$

And rotor mechanical speed can be obtained from equation (8) (Krause, 1986):

$$
T_{e}-T_{m}=J \frac{d \omega_{m}}{d t}+D \omega_{m}
$$

Where $T_{m}$ is mechanical torque, $T_{e}$ is generator torque, $D$ is system drag (friction) coefficient and $\mathrm{J}$ is total inertia.

In induction machine with rotor configuration that is referred to as a winding rotor, rotor external resistance is used to increase slip and its amount is usually low and is nearly one over ten percent of rotor resistance per phase.

In doubly-fed induction generator, an external source with adjustable amplitude and phase is used to control induction generator speed and power (Ehernberg et al., 2001).

According to table 3 and by using induction machine model of MATLAB-SIMULINK the simulation has been performed.

\begin{tabular}{|c|c|}
\hline Nominal power & $15 \mathrm{~kW}$ \\
\hline Line to line nominal voltage & $460 \mathrm{~V}$ \\
\hline Nominal frequency & $60 \mathrm{HZ}$ \\
\hline Number of pair poles & 4 \\
\hline Stator resistance, $\mathrm{R}_{\mathrm{S}}$ & $0.2761 \Omega$ \\
\hline Stator inductance, $\mathrm{L}_{\mathrm{ls}}$ & $2.2 \mathrm{mH}$ \\
\hline Rotor resistance, $\mathrm{R}_{\mathrm{r}}$ & $0.1645 \Omega$ \\
\hline Rotor inductance, $\mathrm{L}_{\mathrm{lr}}$ & $2.2 \mathrm{mH}$ \\
\hline Magnetizing inductance, $\mathrm{L}_{\mathrm{m}}$ & $76.14 \mathrm{mH}$ \\
\hline Inertia, J & $0.1 \mathrm{~kg} . \mathrm{m}^{2}$ \\
\hline Friction coefficient, $\mathrm{F}$ & $0.018 \mathrm{~N} . \mathrm{m} . \mathrm{s}$ \\
\hline
\end{tabular}

Table 3. Induction machine parameters in side of stator (Hoseinpur et al., 2001) 


\section{Machine simulation results}

Results of simulation of fig.1 are presented in table 4 (Kojooyan Jafari \& Radan, 2008).

Simulation has been performed for 2 seconds, using MATLAB-SIMULINK.

In table4, the polarity of input power to machine is considered negative and that of output from machine is considered positive.

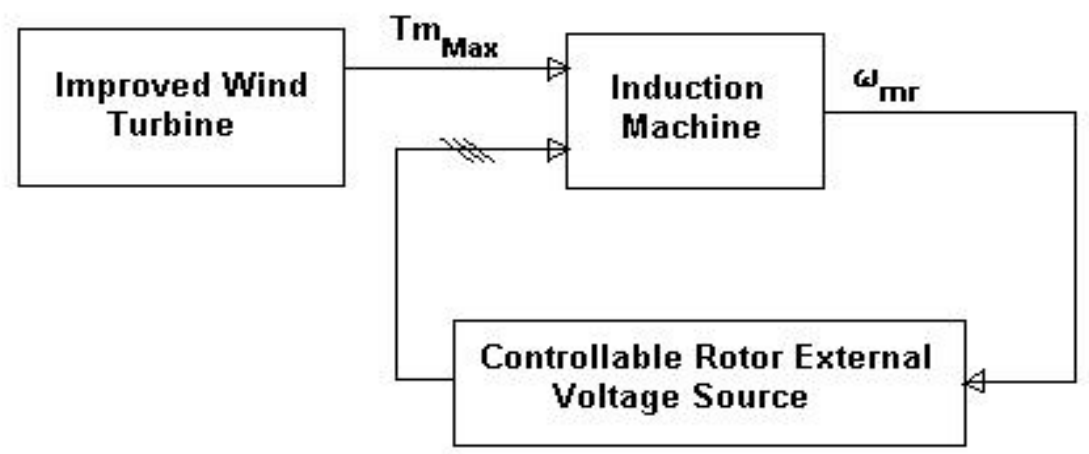

Fig. 1. Model of doubly-fed machine with improved wind turbine

In simulation, the gearbox effect is considered and output torque of gearbox is multiplied by inverse of gear ratio where gear ratio is the ratio of generator shaft speed to low-speed shaft speed in relation to equation (9):

$$
N_{G B}=\frac{\omega_{m r}}{\omega_{T}}
$$

\begin{tabular}{|c|c|c|c|c|c|c|c|c|}
\hline $\mathrm{V}_{\text {wind }}$ & $\mathrm{k}$ & $\theta$ & $\mathrm{r}_{\mathrm{ex}}$ & $\omega_{\mathrm{T}}$ & $\omega_{\mathrm{mr}}$ & $\begin{array}{c}\mathrm{N} \\
\mathrm{g}\end{array}$ & $\mathrm{P}_{\mathrm{T} 3 \Phi}$ & $\mathrm{P}_{\mathrm{S} 3 \Phi}$ \\
\hline 4 & 5 & -0.02 & 0.016 & 6.28 & 94.5 & 15 & $-1.8 \mathrm{k}$ & $1.4 \mathrm{k}$ \\
\hline 4 & 5 & -0.78 & 0.016 & 6.28 & 94.5 & 15 & $-1.8 \mathrm{k}$ & $1.4 \mathrm{k}$ \\
\hline 4 & 10 & -0.02 & 0.016 & 6.28 & 94.5 & 15 & $-1.8 \mathrm{k}$ & $1.4 \mathrm{k}$ \\
\hline 4 & 10 & -0.78 & 0.016 & 6.28 & 94.5 & 15 & $-1.8 \mathrm{k}$ & $1.4 \mathrm{k}$ \\
\hline 5 & 15 & -0.02 & 0.016 & 7.85 & 95 & 12 & $-3.53 \mathrm{k}$ & $3 \mathrm{k}$ \\
\hline 5 & 15 & -0.78 & 0.016 & 7.85 & 95 & 12 & $-3.53 \mathrm{k}$ & $3 \mathrm{k}$ \\
\hline 5 & 20 & -0.02 & 0.016 & 7.85 & 95 & 12 & $-3.53 \mathrm{k}$ & $3 \mathrm{k}$ \\
\hline 5 & 20 & -0.78 & 0.016 & 7.85 & 95 & 12 & $-3.53 \mathrm{k}$ & $3.53 \mathrm{k}$ \\
\hline
\end{tabular}

Table 4. Simulation results of wind turbine and doubly-fed generator 


\begin{tabular}{|c|c|c|c|c|c|c|}
\hline $\mathrm{V}_{\text {wind }}$ & $\mathrm{k}$ & $\mathrm{r}_{\mathrm{ex}}$ & $\mathrm{P}_{\mathrm{r} 3 \Phi}$ & $\mathrm{P}_{\text {loss }}$ & $\mathrm{Q}_{\mathrm{S} 3 \Phi}$ & $\mathrm{Q}_{\mathrm{r} 3 \Phi}$ \\
\hline 4 & 5 & 0.016 & 6 & 394 & $-7.5 \mathrm{k}$ & 11.5 \\
\hline 4 & 5 & 0.016 & 6 & 394 & $-7.5 \mathrm{k}$ & 11.5 \\
\hline 4 & 10 & 0.016 & 10 & 390 & $-8.5 \mathrm{k}$ & 47 \\
\hline 4 & 10 & 0.016 & 10 & 390 & $-8.5 \mathrm{k}$ & 47 \\
\hline 5 & 15 & 0.016 & 7 & 523 & $-8 \mathrm{k}$ & 21 \\
\hline 5 & 15 & 0.016 & 7 & 523 & $-8 \mathrm{k}$ & 21 \\
\hline 5 & 20 & 0.016 & 10 & 480 & $-8.5 \mathrm{k}$ & 40 \\
\hline 5 & 20 & 0.016 & 10 & 480 & $-8.5 \mathrm{k}$ & 40 \\
\hline
\end{tabular}

Table 4. (continue)

Where $\mathrm{k}$ and $\theta$ are amplitude and phase of external rotor source, $\mathrm{r}_{\mathrm{ex}}$ is external rotor resistance, $\mathrm{Q}_{\mathrm{S} 3 \Phi}$ and $\mathrm{Q}_{\mathrm{r} 3 \Phi}$ are 3-phased reactive power of rotor and stator in VAR, $\mathrm{P}_{\mathrm{T} 3 \Phi}$ is maximum turbine power, $\mathrm{P}_{\mathrm{r} 3 \Phi}$ and $\mathrm{P}_{\mathrm{S} 3 \Phi}$ are 3-phased active power of rotor and stator and $P_{\text {loss }}$ is power losses of machine that all are in watt, $\omega_{\mathrm{T}}$ is turbine speed in $\mathrm{rad} / \mathrm{sec}, \mathrm{V}_{\text {wind }}$ is wind speed in $\mathrm{m} / \mathrm{s}, \omega_{\mathrm{mr}}$ is mechanical speed of rotor in $\mathrm{rad} / \mathrm{sec}$ and $\mathrm{Ng}$ is ratio of gear

Table5 shows the results of simulation for two amounts of external rotor resistance.

\begin{tabular}{|c|c|c|c|c|c|c|c|}
\hline $\mathrm{V}_{\text {wind }}$ & $\mathrm{k}$ & $\theta$ & $\mathrm{r}_{\mathrm{ex}}$ & $\omega_{\mathrm{T}}$ & $\omega_{\mathrm{mr}}$ & $\mathrm{Ng}$ & $\mathrm{Q}_{\mathrm{r} 3 \Phi}$ \\
\hline 4 & 10 & -0.78 & 0.016 & 6.28 & 94.5 & 15 & 47 \\
\hline 4 & 10 & -0.78 & 3 & 6.28 & 96.7 & 15.4 & -1 \\
\hline 5 & 15 & -0.78 & 0.016 & 7.85 & 95 & 12 & 21 \\
\hline 5 & 15 & -0.78 & 3 & 7.85 & 99 & 12.6 & -0.5 \\
\hline
\end{tabular}

Table 5. Simulation results of wind turbine with doubly-fed generator for two different $r_{e x}$

\begin{tabular}{|c|c|c|c|c|c|c|}
\hline $\mathrm{V}_{\text {wind }}$ & $\mathrm{k}$ & $\mathrm{Q}_{\mathrm{S} 3 \Phi}$ & $\mathrm{P}_{\mathrm{T} 3 \Phi}$ & $\mathrm{P}_{\mathrm{S} 3 \Phi}$ & $\mathrm{P}_{\mathrm{r} 3 \Phi}$ & $\mathrm{P}_{\text {loss }}$ \\
\hline 4 & 10 & $-8.5 \mathrm{k}$ & $-1.8 \mathrm{k}$ & $1.4 \mathrm{k}$ & 10 & 390 \\
\hline 4 & 10 & $-7.2 \mathrm{k}$ & $-1.8 \mathrm{k}$ & $1.5 \mathrm{k}$ & -0.5 & 300.5 \\
\hline 5 & 15 & $-8 \mathrm{k}$ & $-3.53 \mathrm{k}$ & $3 \mathrm{k}$ & 7 & 523 \\
\hline 5 & 15 & $-7.3 \mathrm{k}$ & $-3.53 \mathrm{k}$ & $3.1 \mathrm{k}$ & 2 & 428 \\
\hline
\end{tabular}

Table 5. (continue)

The curves of simulation are presented in the following figs.2 to 17 (Kojooyan Jafari \& Radan, 2009). 


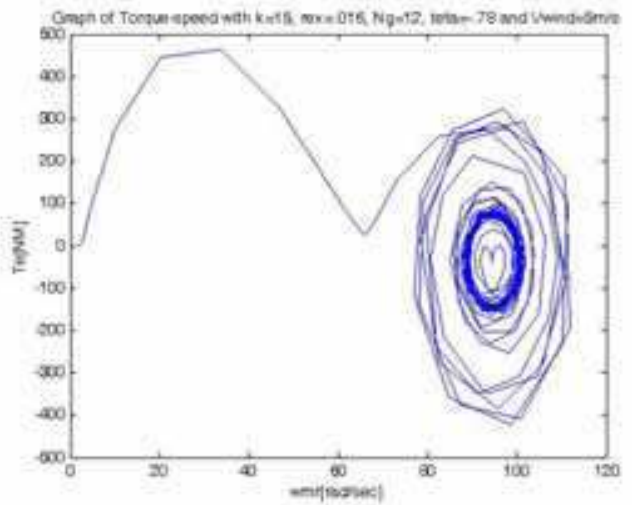

Fig. 2. Curve of torque-speed for $\mathrm{k}=15, \mathrm{r}_{\mathrm{ex}}=0.016, \mathrm{~V}_{\text {wind }}=5, \theta=-0.78$ and $\mathrm{Ng}=12$

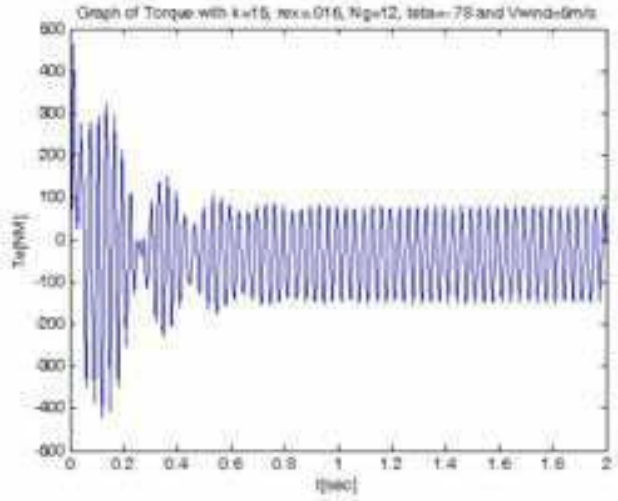

Fig. 3. Curve of electromagnetic torque-time for $k=15, r_{e x}=0.016, V_{\text {wind }}=5, \theta=-0.78$ and $\mathrm{Ng}=12$

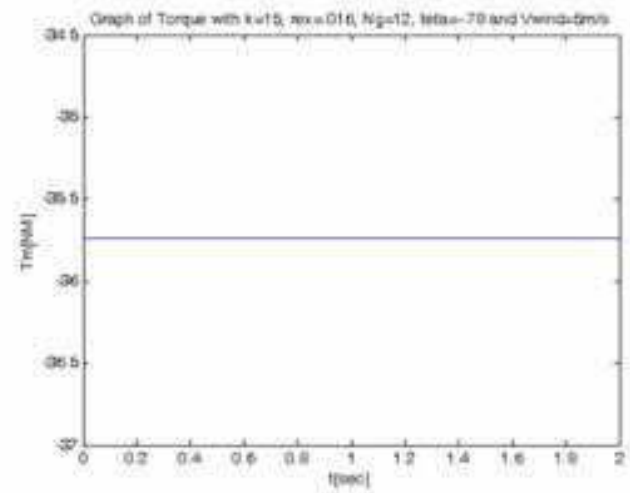

Fig. 4. Curve of mechanical torque-time for $\mathrm{k}=15, \mathrm{r}_{\mathrm{ex}}=0.016, \mathrm{~V}_{\text {wind }}=5, \theta=-0.78$ and $\mathrm{Ng}=12$ 


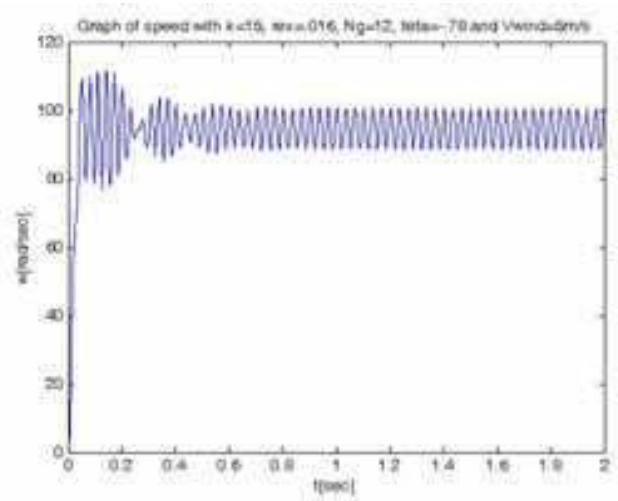

Fig. 5. Curve of mechanical rotor speed-time for $\mathrm{k}=15, \mathrm{r}_{\mathrm{ex}}=0.016, \mathrm{~V}_{\text {wind }}=5, \theta=-0.78$ and $\mathrm{Ng}=12$

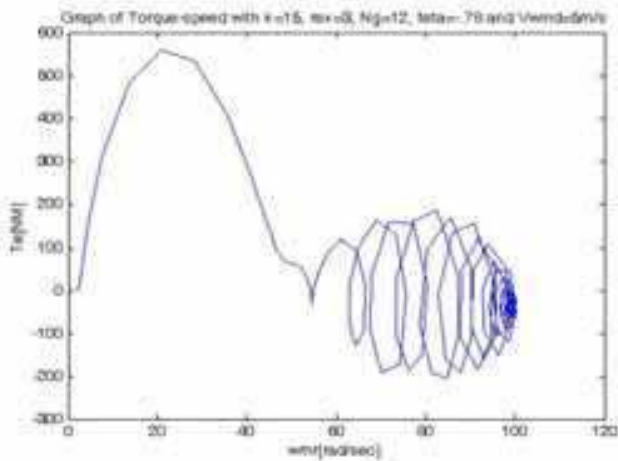

Fig. 6. Curve of torque-speed for $\mathrm{k}=15, \mathrm{r}_{\mathrm{ex}}=3, \mathrm{~V}_{\text {wind }}=5, \theta=-0.78$ and $\mathrm{Ng}=12$

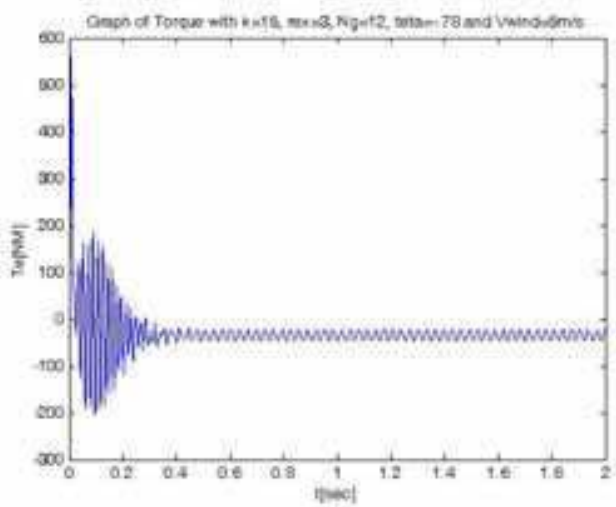

Fig. 7. Curve of electromagnetic torque-time for $\mathrm{k}=15, \mathrm{r}_{\mathrm{ex}}=3, \mathrm{~V}_{\text {wind }}=5, \theta=-0.78$ and $\mathrm{Ng}=12$ 


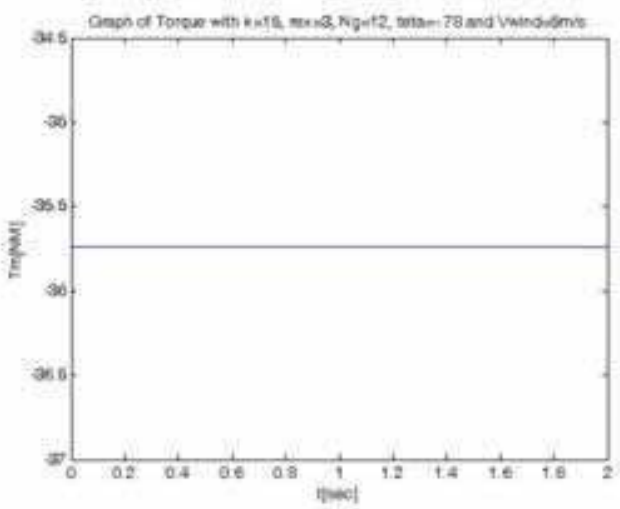

Fig. 8. Curve of mechanical torque-time for $\mathrm{k}=15, \mathrm{r}_{\mathrm{ex}}=3, \mathrm{~V}_{\text {wind }}=5, \theta=-0.78$ and $\mathrm{Ng}=12$

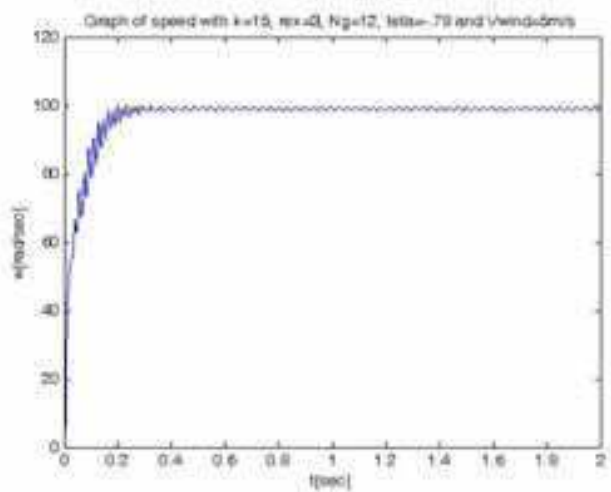

Fig. 9. Curve of mechanical rotor speed-time for $k=15, r_{e x}=3, V_{\text {wind }}=5, \theta=-0.78$ and $N g=12$

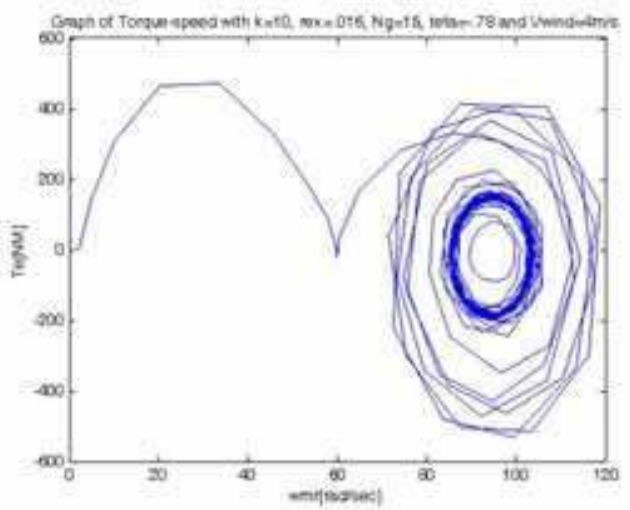

Fig. 10. Curve of torque-speed for $\mathrm{k}=10, \mathrm{r}_{\mathrm{ex}}=0.016, \mathrm{~V}_{\text {wind }}=4, \theta=-0.78$ and $\mathrm{Ng}=15$ 


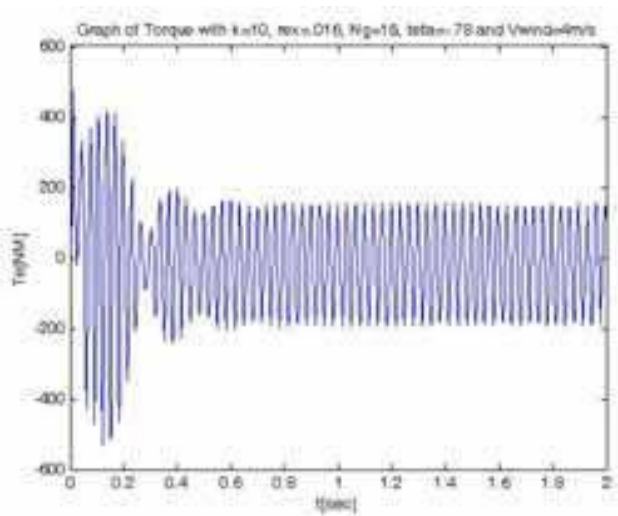

Fig. 11. Curve of electromagnetic torque-time for $\mathrm{k}=10, \mathrm{r}_{\mathrm{ex}}=0.016, \mathrm{~V}_{\text {wind }}=4, \theta=-0.78$ and $\mathrm{Ng}=15$

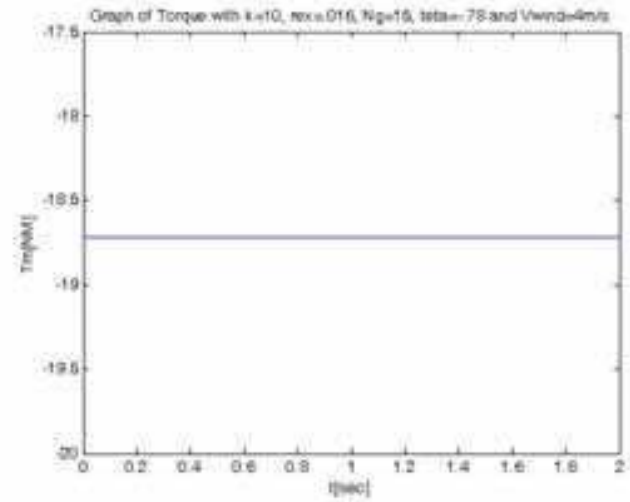

Fig. 12. Curve of mechanical torque-time for $\mathrm{k}=10, \mathrm{r}_{\mathrm{ex}}=0.016, \mathrm{~V}_{\text {wind }}=4, \theta=-0.78$ and $\mathrm{Ng}=15$

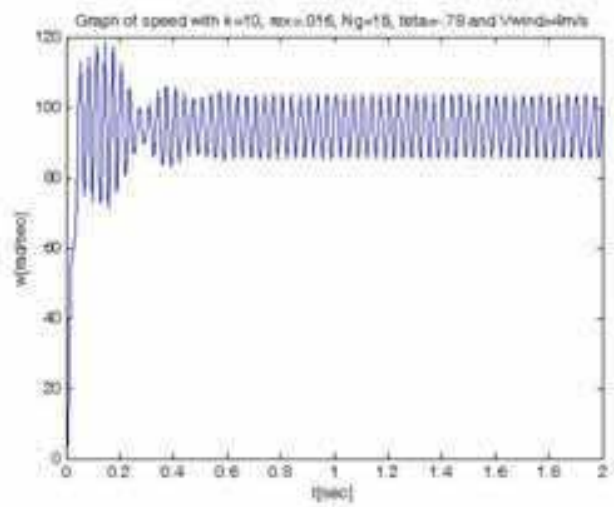

Fig. 13. Curve of mechanical rotor speed-time for $\mathrm{k}=10, \mathrm{r}_{\mathrm{ex}}=0.016, \mathrm{~V}_{\text {wind }}=4, \theta=-0.78$ and $\mathrm{Ng}=15$ 


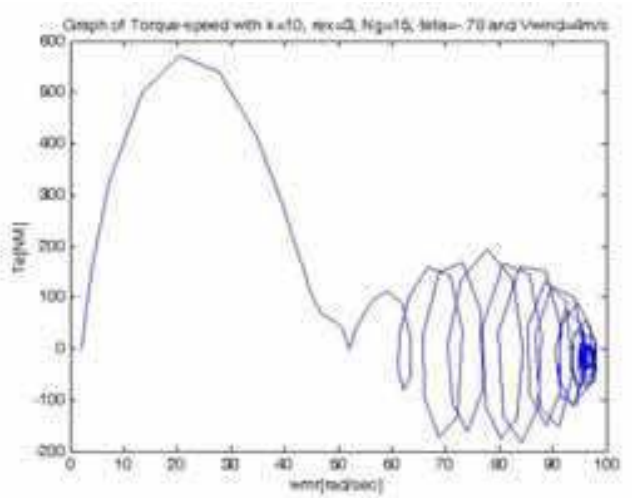

Fig. 14. Curve of torque-speed for $\mathrm{k}=10, \mathrm{r}_{\mathrm{ex}}=3, \mathrm{~V}_{\text {wind }}=4, \theta=-0.78$ and $\mathrm{Ng}=15$

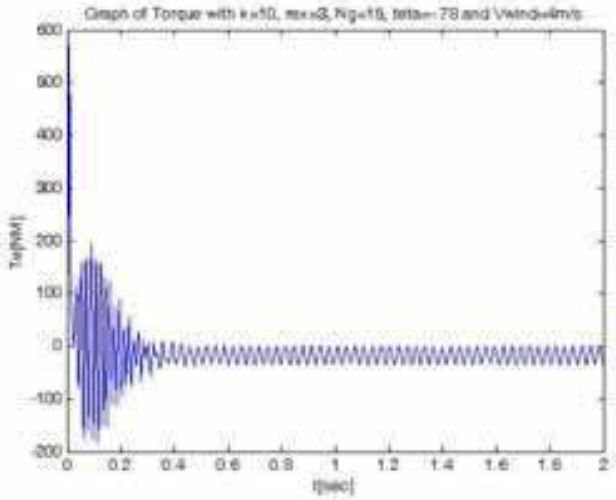

Fig. 15. Curve of electromagnetic torque-time for $k=10, r_{e x}=3, V_{\text {wind }}=4, \theta=-0.78$ and $N g=15$

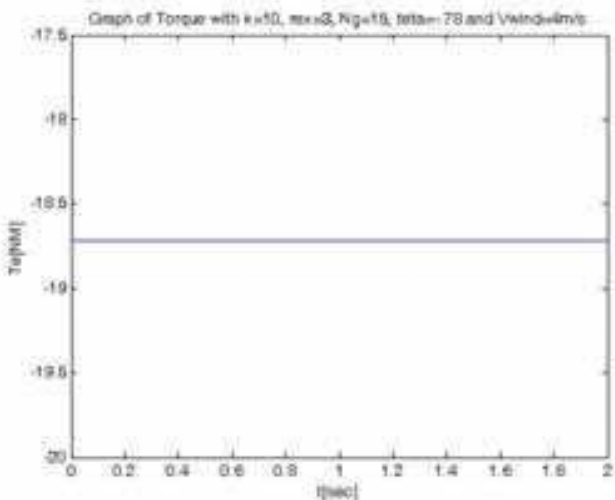

Fig. 16. Curve of mechanical torque-time for $\mathrm{k}=10, \mathrm{r}_{\mathrm{ex}}=3, \mathrm{~V}_{\text {wind }}=4, \theta=-0.78$ and $\mathrm{Ng}=15$ 


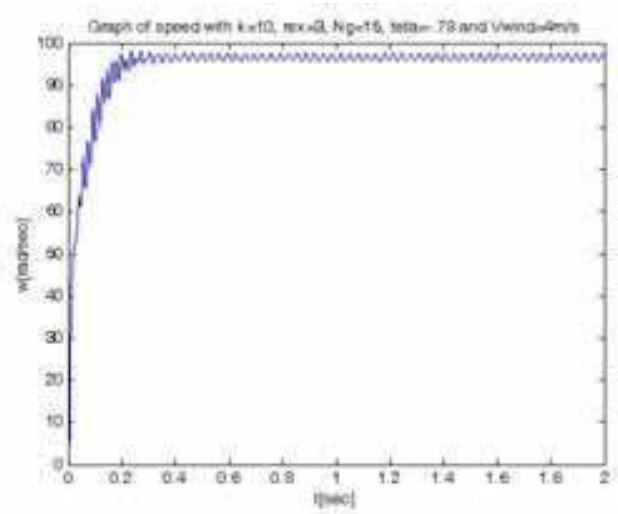

Fig. 17. Curve of mechanical rotor speed-time for $\mathrm{k}=10, \mathrm{r}_{\mathrm{ex}}=3, \mathrm{~V}_{\text {wind }}=4, \theta=-0.78$ and $\mathrm{Ng}=15$

\section{PI self tuning voltage controller}

One of the most important subjects is control of output power when rotor external voltage source domain drops down.A PI self tuning voltage controller, shown in Fig.18, controls stator output power through adjusting the voltage at rotor terminals. $\mathrm{V}_{\text {wind }}$ in diagram is related to $\omega_{\mathrm{M}}$ of turbine according to the equation (1). For self tuning control, $\mathrm{P}$ parameter of controller is adopted by $\mathrm{k}$; domain of external rotor source according to fig. 19 and equation (9) when I parameter is constant and 0.0001, in every low and high wind speed (Kojooyan Jafari \& Radan, 2010).

$$
p=8 / k
$$

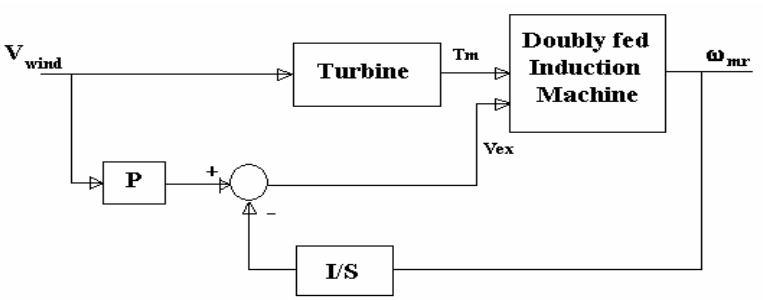

Fig. 18. Block diagram of PI self tuning voltage controller

\section{PI self tuning combined voltage and pitch controller}

A P self tuning voltage and pitch controller controls the system proportionally according to fig.20 then torque compensation is exerted whereas maximum turbine torque according to equation (3) can be achieved and stator output power is controlled consequently.

In this system self tuning combined control is designed by constant parameters of $P_{1}$ and $P_{2}$ according to table 10 . 


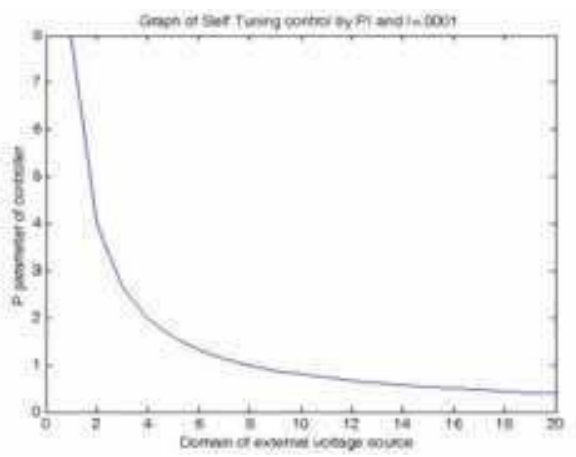

Fig. 19. Curve of $\mathrm{P}$ parameter when domain of external rotor source changes while I parameter is 0.0001

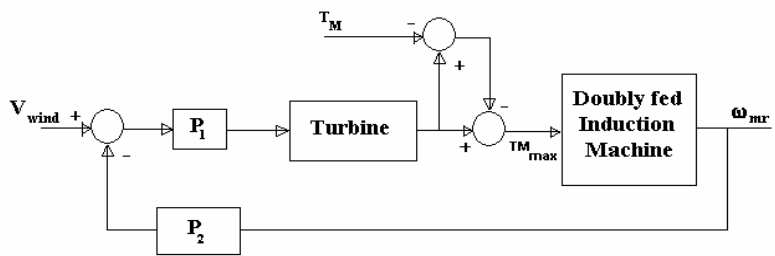

Fig. 20. Block diagram of P combined controller

\section{Controllers simulation results}

The results of simulation for reference points of tables 6 to 9 with parameters of PI and P controllers according to table 10 are presented in figs. 21 to 68 for a typical wind speed; $6 \mathrm{~m} / \mathrm{s}$, for self tuning PI and P controllers.

In table 6, the polarity of input power to machine is considered negative and that of output from machine is considered positive for set points of tables 6 to 9 . Table 10 shows parameters of controllers.

In simulation, the gearbox effect is considered in such a way that output torque of gearbox is multiplied by inverse of gear ratio.

\begin{tabular}{|c|c|c|c|}
\hline \#Points & $\omega_{\mathrm{mr}[\mathrm{rad} / \mathrm{s}]}$ & $\mathrm{P}_{\mathrm{s}[\mathrm{W}]}$ & $\mathrm{Q}_{\mathrm{s}[\mathrm{VAR}]}$ \\
\hline 1 & 96.6 & $1.5 \mathrm{k}$ & $-7.2 \mathrm{k}$ \\
\hline 2 & 98.9 & $3 \mathrm{k}$ & $-7.3 \mathrm{k}$ \\
\hline 3 & 117 & $15.2 \mathrm{k}$ & $-9.4 \mathrm{k}$ \\
\hline
\end{tabular}

Table 6. Three reference point characteristic

\begin{tabular}{|c|c|}
\hline $\mathrm{V}_{\text {wind }[\mathrm{m} / \mathrm{s}]}$ & $\mathrm{N}_{\mathrm{g}}$ \\
\hline 4 & 15.4 \\
\hline 5 & 24 \\
\hline 6 & 34 \\
\hline 12 & 140 \\
\hline
\end{tabular}

Table 7. $\mathrm{N}_{\mathrm{G}}$ differences for the first reference point 


\begin{tabular}{|c|c|}
\hline $\mathrm{V}_{\text {wind[m } / \mathrm{s}]}$ & $\mathrm{N}_{\mathrm{g}}$ \\
\hline 4 & 8 \\
\hline 5 & 15.4 \\
\hline 6 & 17 \\
\hline 12 & 74 \\
\hline
\end{tabular}

Table 8. $\mathrm{N}_{\mathrm{G}}$ differences for the second reference point

\begin{tabular}{|c|c|}
\hline $\mathrm{V}_{\text {wind[m/s] }}$ & $\mathrm{N}_{\mathrm{g}}$ \\
\hline 4 & 1.7 \\
\hline 5 & 2.6 \\
\hline 6 & 3.8 \\
\hline 12 & 15.4 \\
\hline
\end{tabular}

Table 9. $\mathrm{N}_{\mathrm{G}}$ differences for third reference point

When k; rotor external voltage domain of system with PI controller, drops down from 10 to 2 in relation to figs. 21 to 68 , P parameter of self tuning PI controller can control the system according to equation (9) and table 10; however, constant parameters of self tuning $\mathrm{P}$ controller control the system without change according to table 10, when domain of rotor external voltage source drops down.

\begin{tabular}{|c|c|c|c|}
\hline P of PI & I of PI & $\mathrm{P}_{1}$ of $\mathrm{P}$ & $\mathrm{P}_{2}$ of $\mathrm{P}$ \\
\hline $8 / \mathrm{k}$ & .0001 & .8 & .1 \\
\hline
\end{tabular}

Table 10. Parameters of Controllers

Simulation has been done for both PI, as shown in figs. 21 to 44 and P according to Figs. 45 to 68 . Stator active and reactive powers delivered to the grid are controlled by both P and PI controllers; however it is seen that output responses of the system with P controller has less swing in relation to figs. 45 to 68 furthermore when k drops down from 10 to 2 according to the figs. 21 to 68 it is inferred that $\mathrm{P}$ controller can control the stator active and reactive powers with decreasing swing of them; however, PI controller controls the stator active and reactive powers without any change in them. Also torque speed curves show stability of machine and rotor currents are in sinusoidal form.

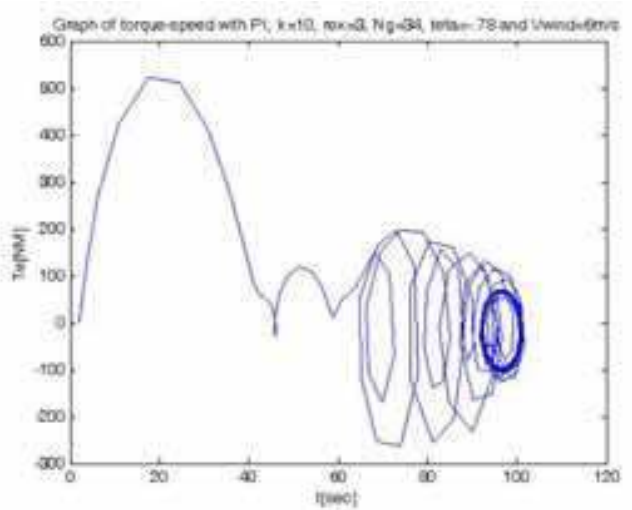

Fig. 21. Curve of torque-speed for typical $\mathrm{v}_{\text {wind }}=6 \mathrm{~m} / \mathrm{s}, \mathrm{k}=10, \mathrm{Ng}=34$ and PI controller. 


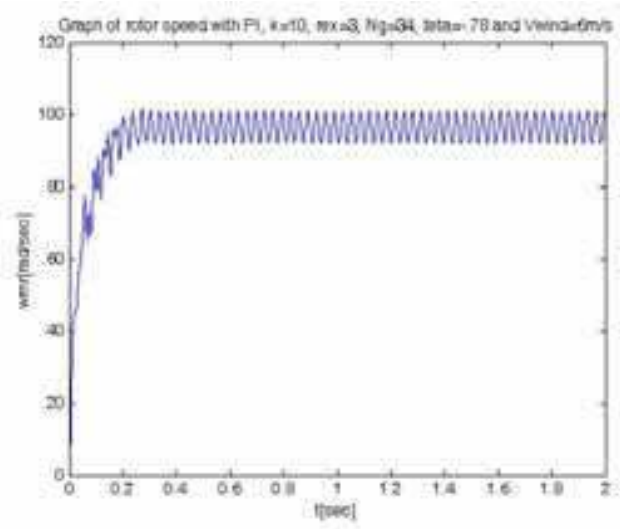

Fig. 22. Curve of rotor speed for typical $\mathrm{v}_{\text {wind }}=6 \mathrm{~m} / \mathrm{s}, \mathrm{k}=10, \mathrm{Ng}=34$ and PI controller.

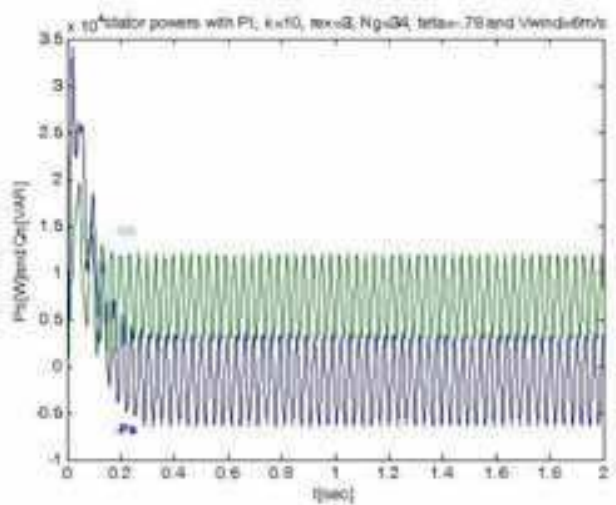

Fig. 23. Curve of stator powers for typical $\mathrm{v}_{\text {wind }}=6 \mathrm{~m} / \mathrm{s}, \mathrm{k}=10, \mathrm{Ng}=34$ and PI controller.

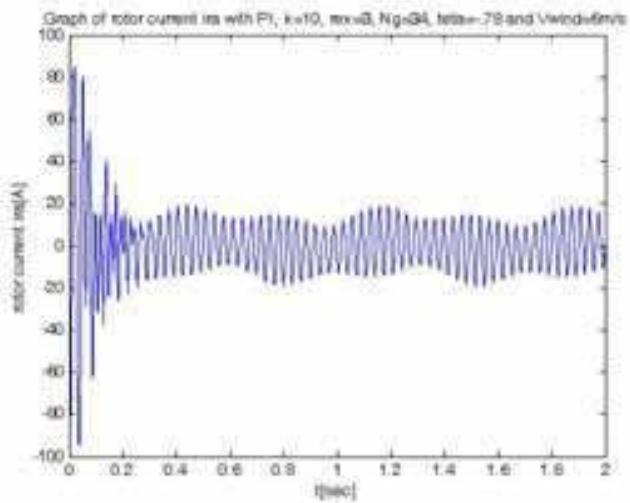

Fig. 24. Curve of rotor current $i_{\text {ra }}$ for typical $v_{\text {wind }}=6 \mathrm{~m} / \mathrm{s}, \mathrm{k}=10, \mathrm{Ng}=34$ and PI controller. 


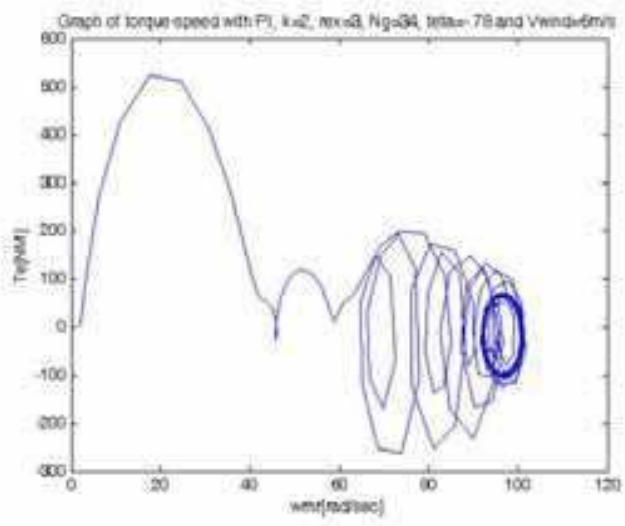

Fig. 25. Curve of torque-speed for typical $\mathrm{v}_{\text {wind }}=6 \mathrm{~m} / \mathrm{s}, \mathrm{k}=2, \mathrm{Ng}=34$ and PI controller.

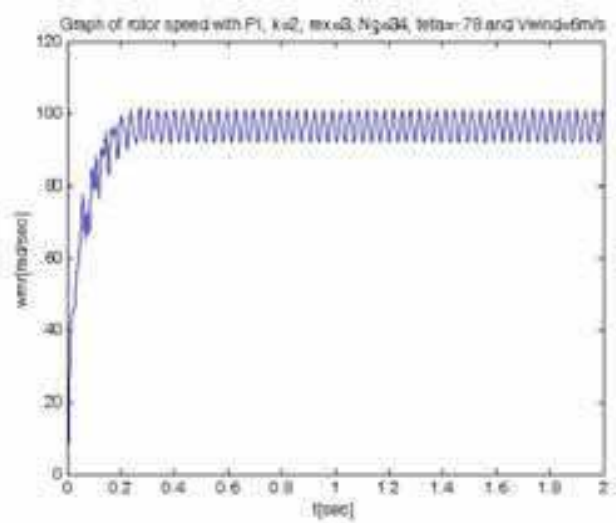

Fig. 26. Curve of rotor speed for typical $\mathrm{v}_{\text {wind }}=6 \mathrm{~m} / \mathrm{s}, \mathrm{k}=2, \mathrm{Ng}=34$ and PI controller.

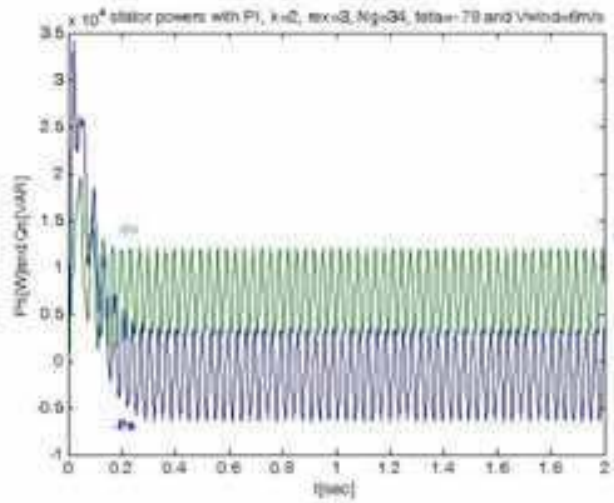

Fig. 27. Curve of stator powers for typical $\mathrm{v}_{\text {wind }}=6 \mathrm{~m} / \mathrm{s}, \mathrm{k}=2, \mathrm{Ng}=34$ and PI controller. 


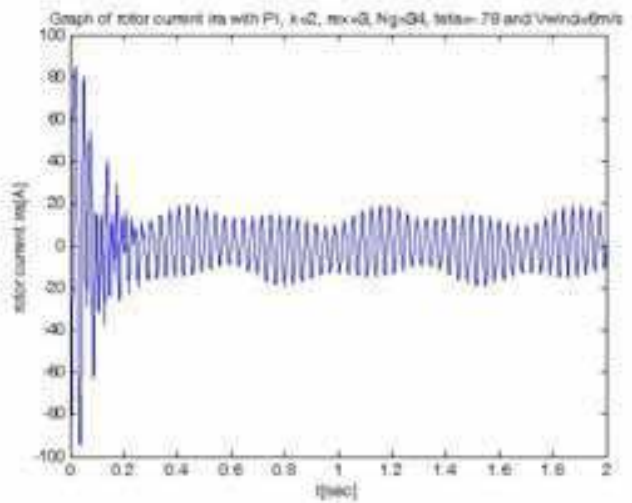

Fig. 28. Curve of rotor current $\mathrm{i}_{\mathrm{ra}}$ for typical $\mathrm{v}_{\text {wind }}=6 \mathrm{~m} / \mathrm{s}, \mathrm{k}=2, \mathrm{Ng}=34$ and PI controller.

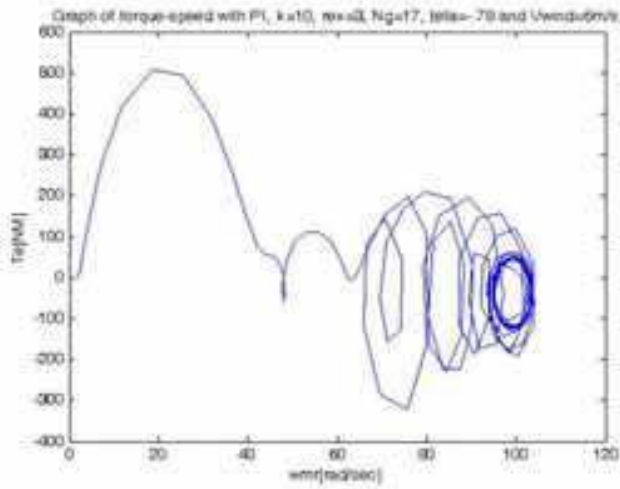

Fig. 29. Curve of torque-speed for typical $\mathrm{v}_{\text {wind }}=6 \mathrm{~m} / \mathrm{s}, \mathrm{k}=10, \mathrm{Ng}=17$ and PI controller.

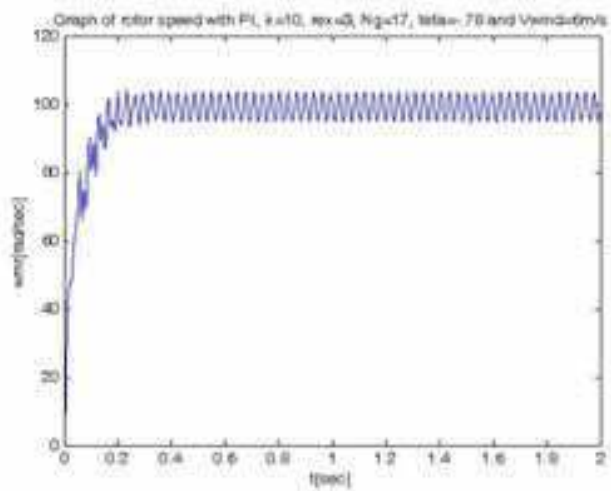

Fig. 30. Curve of rotor speed for typical $\mathrm{v}_{\text {wind }}=6 \mathrm{~m} / \mathrm{s}, \mathrm{k}=10, \mathrm{Ng}=17$ and PI controller. 


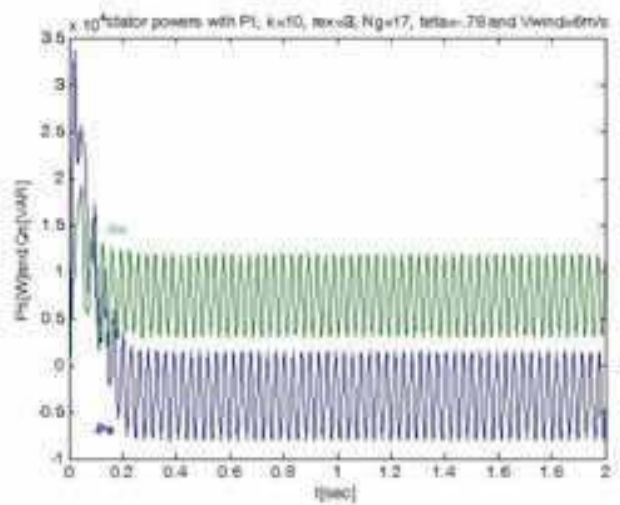

Fig. 31. Curve of stator powers for typical $v_{\text {wind }}=6 \mathrm{~m} / \mathrm{s}, \mathrm{k}=10, \mathrm{Ng}=17$ and PI controller.

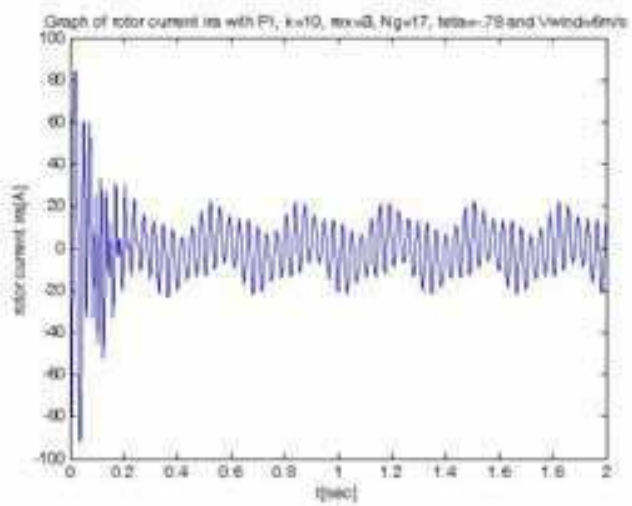

Fig. 32. Curve of rotor current $i_{\text {ra }}$ for typical $v_{\text {wind }}=6 \mathrm{~m} / \mathrm{s}, k=10, N g=17$ and PI controller.

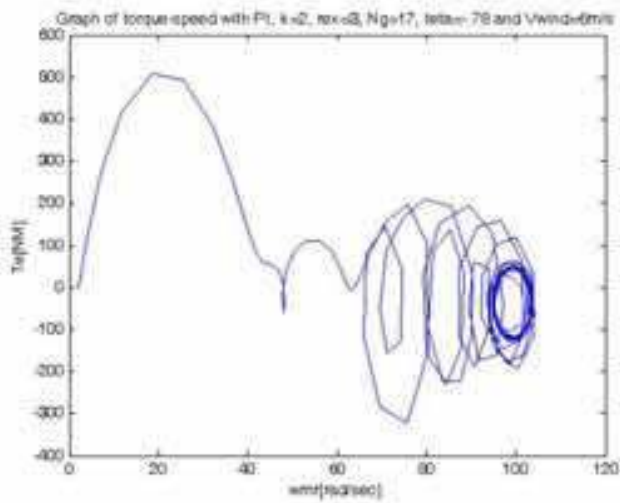

Fig. 33. Curve of torque-speed for typical $\mathrm{v}_{\text {wind }}=6 \mathrm{~m} / \mathrm{s}, \mathrm{k}=2, \mathrm{Ng}=17$ and PI controller. 


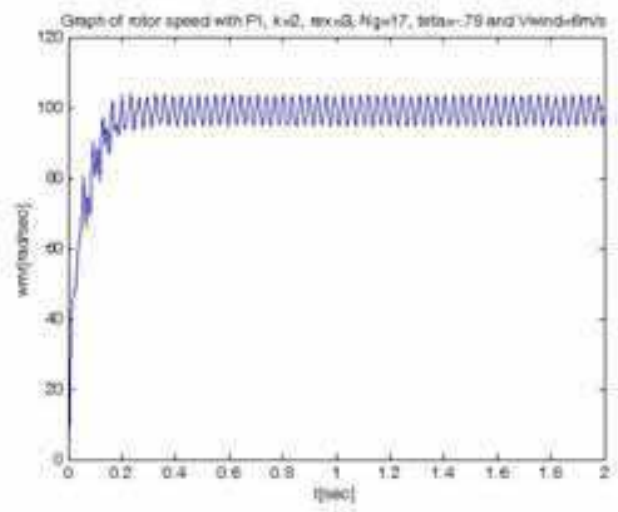

Fig. 34. Curve of rotor speed for typical $\mathrm{v}_{\text {wind }}=6 \mathrm{~m} / \mathrm{s}, \mathrm{k}=2, \mathrm{Ng}=17$ and PI controller.

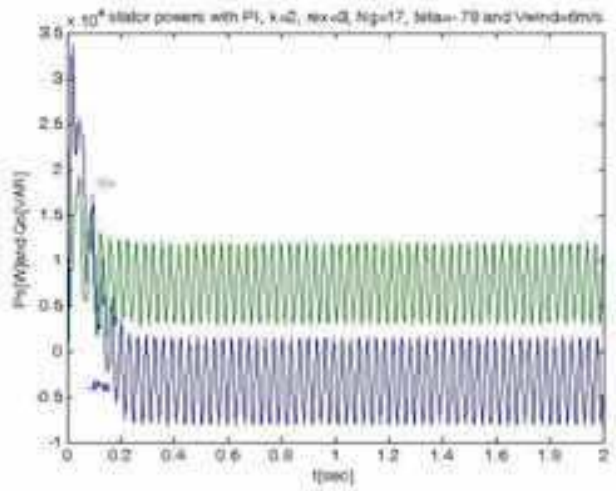

Fig. 35. Curve of stator powers for typical $\mathrm{v}_{\text {wind }}=6 \mathrm{~m} / \mathrm{s}, \mathrm{k}=2, \mathrm{Ng}=17$ and PI controller.

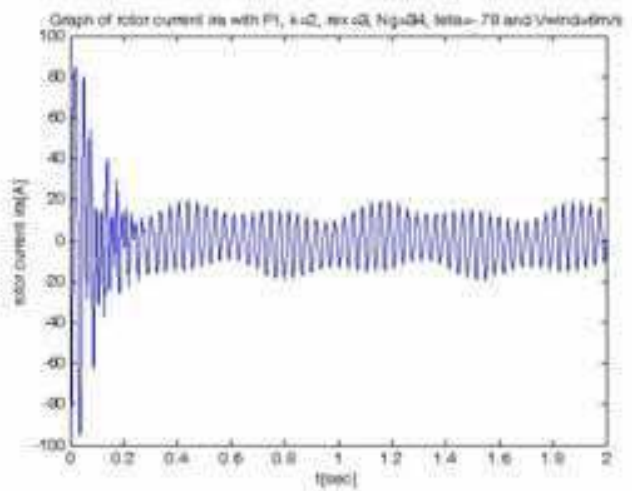

Fig. 36. Curve of rotor current $i_{\text {ra }}$ for typical $v_{\text {wind }}=6 \mathrm{~m} / \mathrm{s}, \mathrm{k}=2, \mathrm{Ng}=17$ and PI controller. 


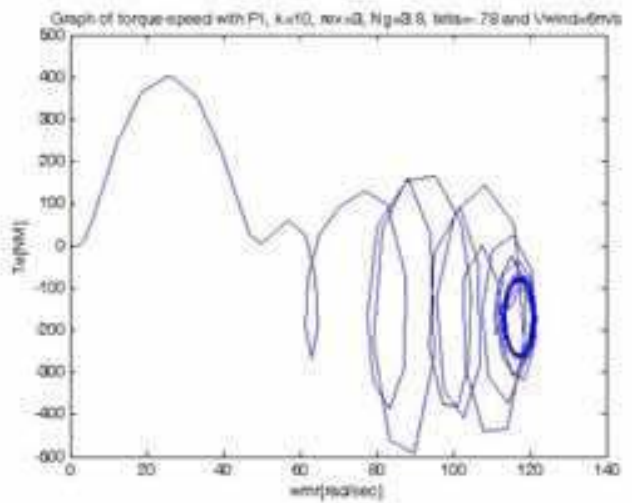

Fig. 37. Curve of torque-speed for typical $\mathrm{v}_{\text {wind }}=6 \mathrm{~m} / \mathrm{s}, \mathrm{k}=10, \mathrm{Ng}=3.8$ and PI controller.

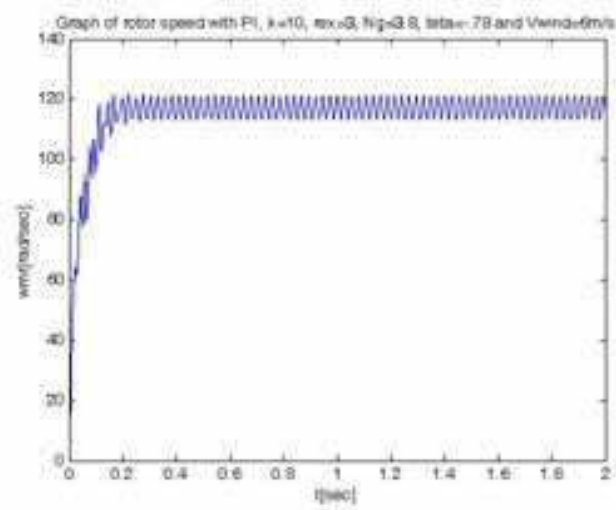

Fig. 38. Curve of rotor speed for typical $\mathrm{v}_{\text {wind }}=6 \mathrm{~m} / \mathrm{s}, \mathrm{k}=10, \mathrm{Ng}=3.8$ and PI controller.

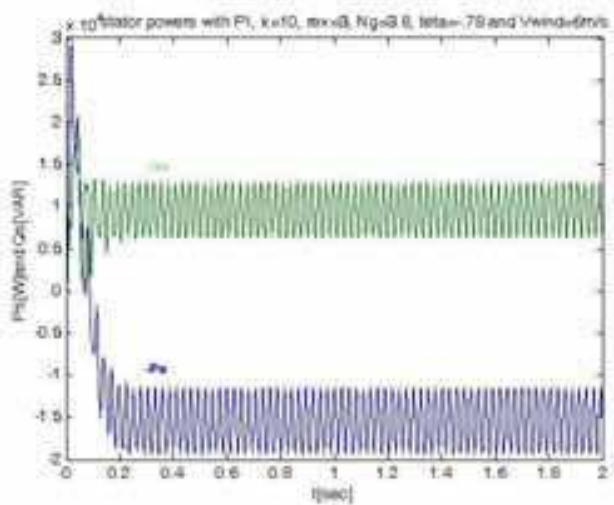

Fig. 39. Curve of stator powers for typical $\mathrm{v}_{\text {wind }}=6 \mathrm{~m} / \mathrm{s}, \mathrm{k}=10, \mathrm{Ng}=3.8$ and PI controller. 


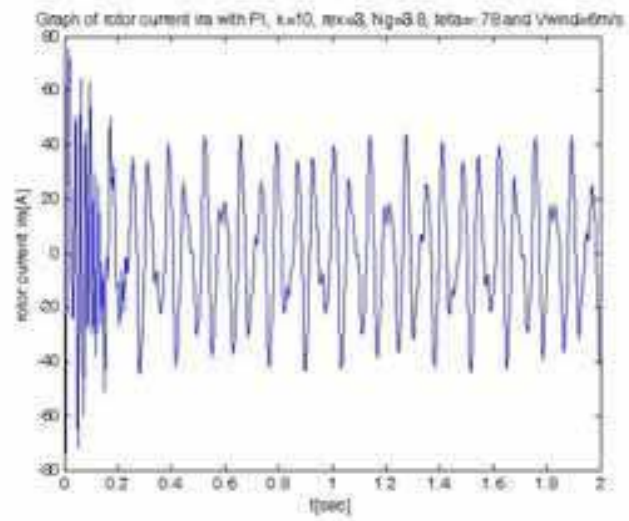

Fig. 40. Curve of rotor current $i_{\text {ra }}$ for typical $v_{\text {wind }}=6 \mathrm{~m} / \mathrm{s}, \mathrm{k}=10, \mathrm{Ng}=3.8$ and PI controller.

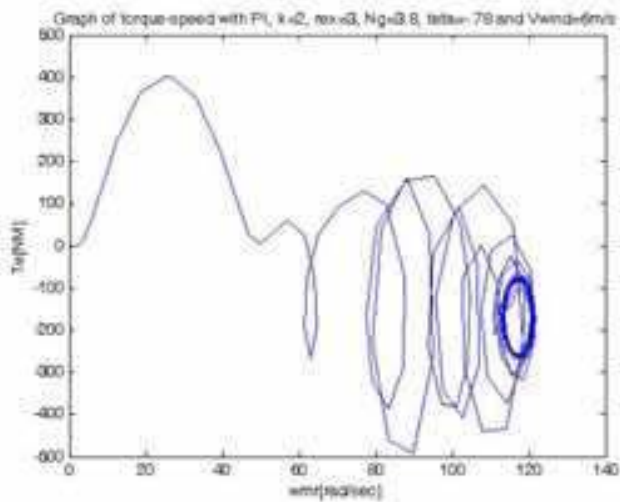

Fig. 41. Curve of torque-speed for typical $\mathrm{v}_{\text {wind }}=6 \mathrm{~m} / \mathrm{s}, \mathrm{k}=2, \mathrm{Ng}=3.8$ and PI controller.

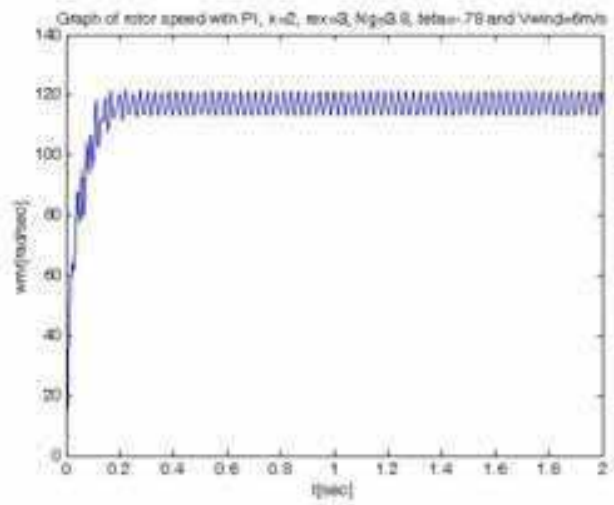

Fig. 42. Curve of rotor speed for typical $\mathrm{v}_{\text {wind }}=6 \mathrm{~m} / \mathrm{s}, \mathrm{k}=2, \mathrm{Ng}=3.8$ and PI controller. 


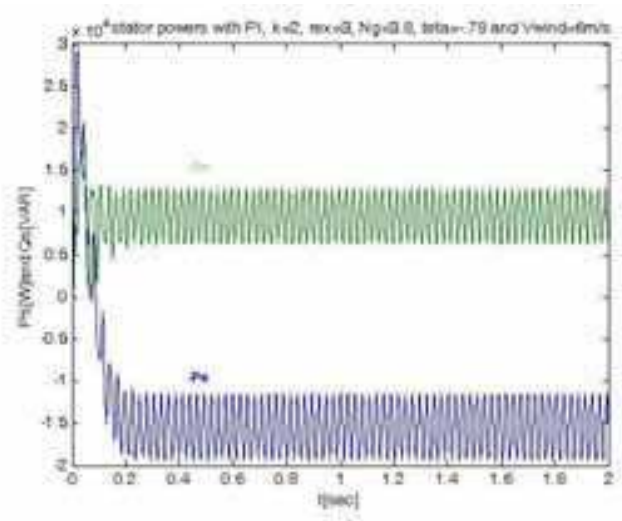

Fig. 43. Curve of stator powers for typical $\mathrm{v}_{\text {wind }}=6 \mathrm{~m} / \mathrm{s}, \mathrm{k}=2, \mathrm{Ng}=3.8$ and PI controller.

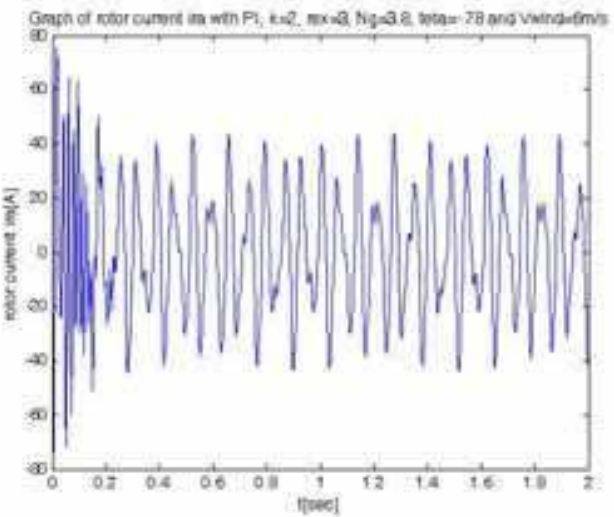

Fig. 44. Curve of rotor current $\mathrm{i}_{\mathrm{ra}}$ for typical $\mathrm{v}_{\text {wind }}=6 \mathrm{~m} / \mathrm{s}, \mathrm{k}=2, \mathrm{Ng}=3.8$ and PI controller.

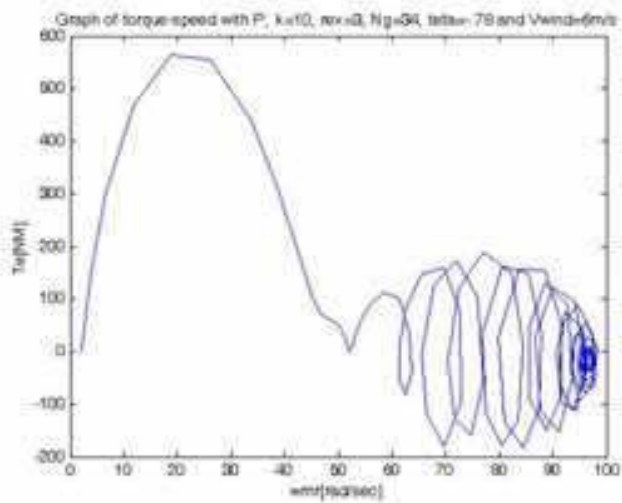

Fig. 45. Curve of torque-speed for typical $\mathrm{v}_{\text {wind }}=6 \mathrm{~m} / \mathrm{s}, \mathrm{k}=10, \mathrm{Ng}=34$ and P controller. 


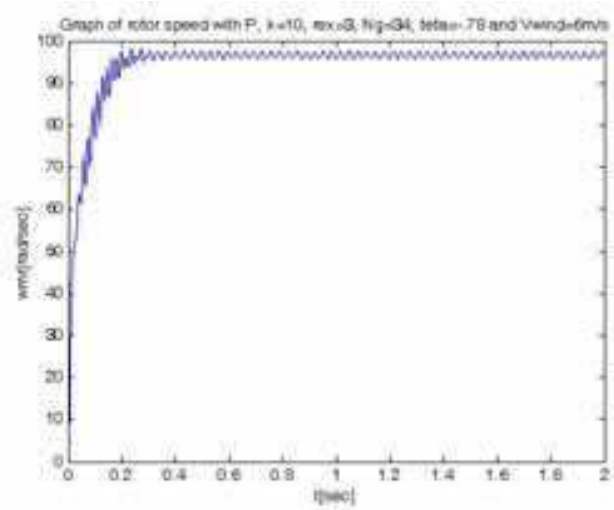

Fig. 46. Curve of rotor speed for typical $\mathrm{v}_{\text {wind }}=6 \mathrm{~m} / \mathrm{s}, \mathrm{k}=10, \mathrm{Ng}=34$ and P controller.

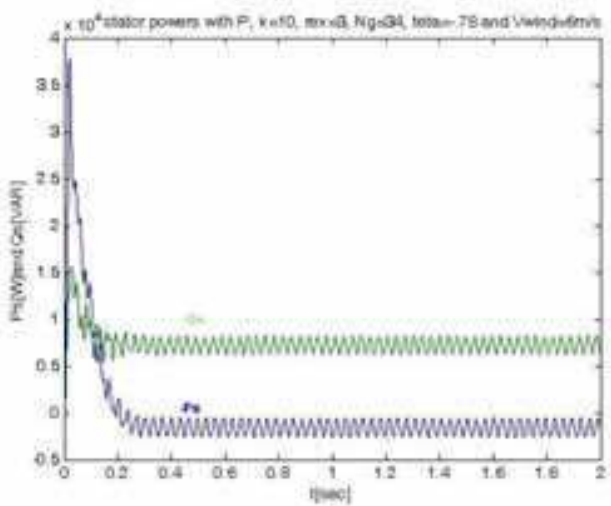

Fig. 47. Curve of stator powers for typical $\mathrm{v}_{\text {wind }}=6 \mathrm{~m} / \mathrm{s}, \mathrm{k}=10, \mathrm{Ng}=34$ and P controller.

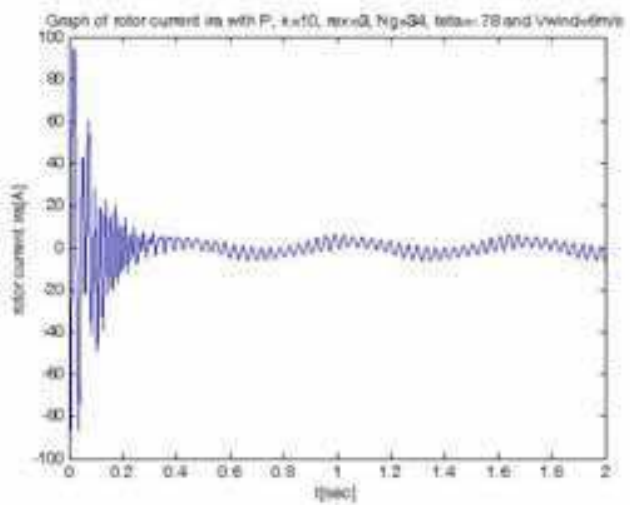

Fig. 48. Curve of rotor current $\mathrm{i}_{\mathrm{ra}}$ for typical $\mathrm{v}_{\text {wind }}=6 \mathrm{~m} / \mathrm{s}, \mathrm{k}=10, \mathrm{Ng}=34$ and $\mathrm{P}$ controller. 


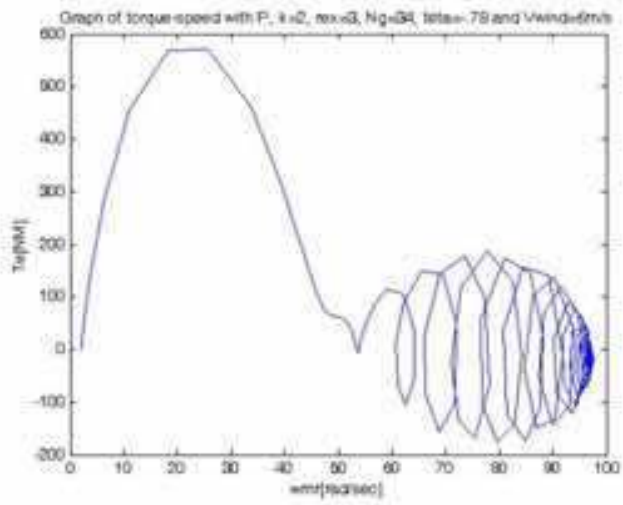

Fig. 49. Curve of torque-speed for typical $\mathrm{v}_{\text {wind }}=6 \mathrm{~m} / \mathrm{s}, \mathrm{k}=2, \mathrm{Ng}=34$ and P controller.

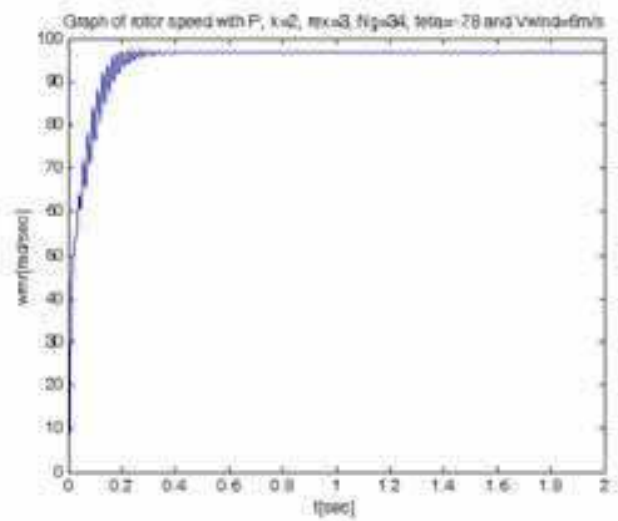

Fig. 50. Curve of rotor speed for typical $\mathrm{v}_{\text {wind }}=6 \mathrm{~m} / \mathrm{s}, \mathrm{k}=2, \mathrm{Ng}=34$ and P controller.

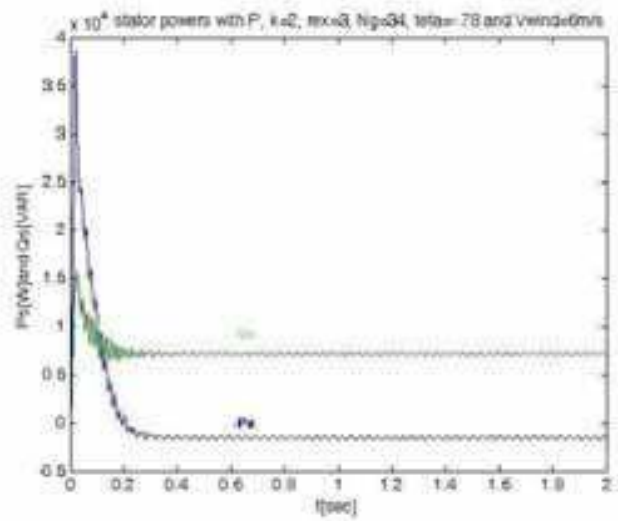

Fig. 51. Curve of stator powers for typical $\mathrm{v}_{\text {wind }}=6 \mathrm{~m} / \mathrm{s}, \mathrm{k}=2, \mathrm{Ng}=34$ and P controller. 


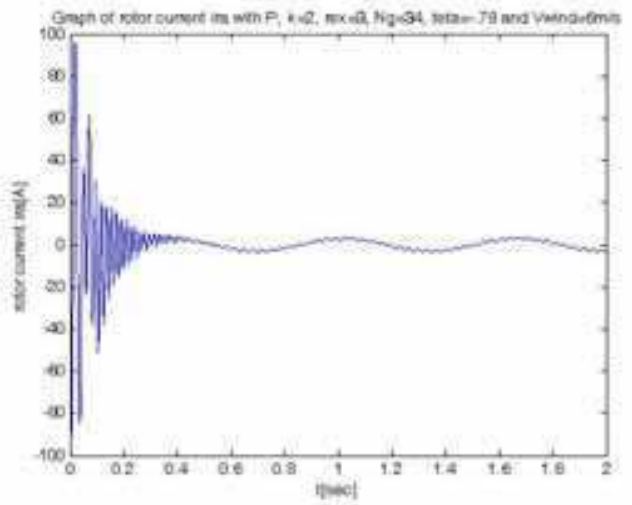

Fig. 52. Curve of rotor current $i_{\text {ra }}$ for typical $v_{\text {wind }}=6 \mathrm{~m} / \mathrm{s}, \mathrm{k}=2, \mathrm{Ng}=34$ and P controller.

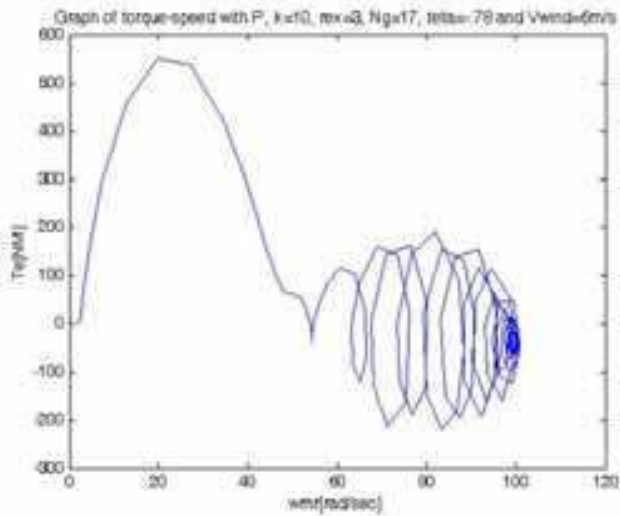

Fig. 53. Curve of torque-speed for typical $\mathrm{v}_{\text {wind }}=6 \mathrm{~m} / \mathrm{s}, \mathrm{k}=10, \mathrm{Ng}=17$ and P controller.

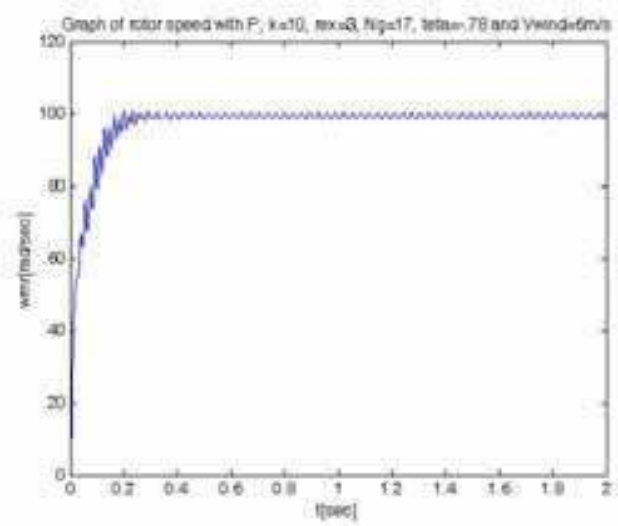

Fig. 54. Curve of rotor speed for typical $\mathrm{v}_{\text {wind }}=6 \mathrm{~m} / \mathrm{s}, \mathrm{k}=10, \mathrm{Ng}=17$ and P controller. 


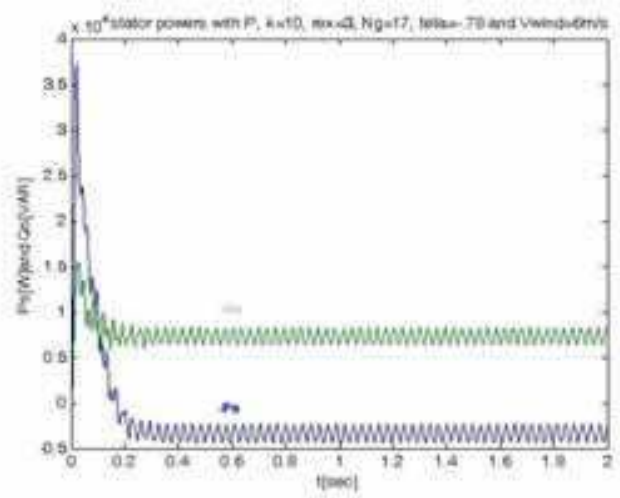

Fig. 55. Curve of stator powers for typical $\mathrm{v}_{\text {wind }}=6 \mathrm{~m} / \mathrm{s}, \mathrm{k}=10, \mathrm{Ng}=17$ and P controller.

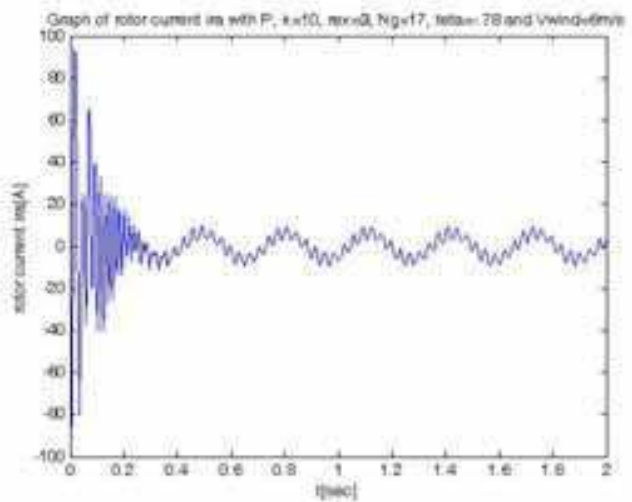

Fig. 56. Curve of rotor current $i_{\mathrm{ra}}$ for typical $v_{\text {wind }}=6 \mathrm{~m} / \mathrm{s}, \mathrm{k}=10, \mathrm{Ng}=17$ and P controller.

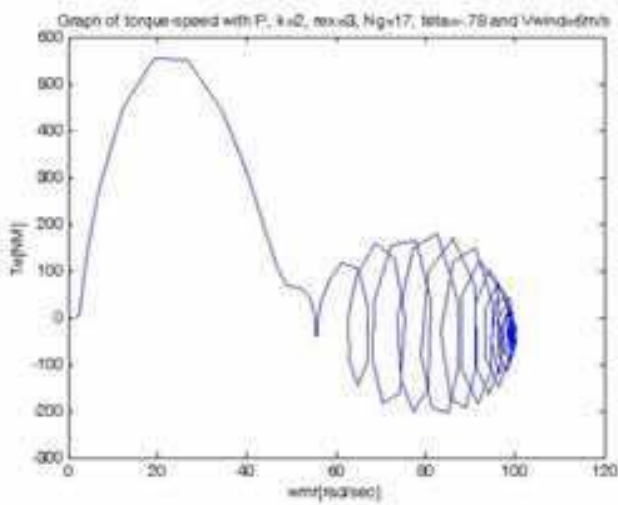

Fig. 57. Curve of torque-speed for typical $\mathrm{v}_{\text {wind }}=6 \mathrm{~m} / \mathrm{s}, \mathrm{k}=2, \mathrm{Ng}=17$ and P controller. 


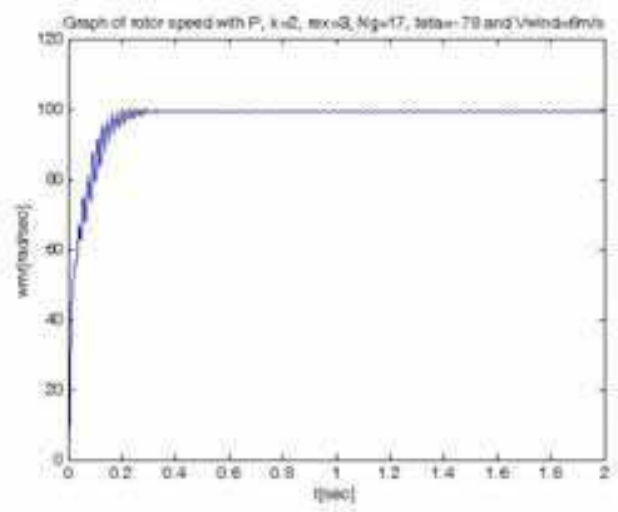

Fig. 58. Curve of rotor speed for typical $\mathrm{v}_{\text {wind }}=6 \mathrm{~m} / \mathrm{s}, \mathrm{k}=2, \mathrm{Ng}=17$ and $\mathrm{P}$ controller.

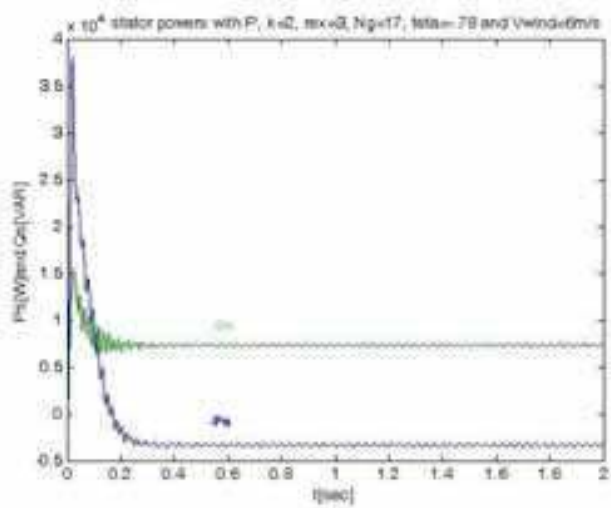

Fig. 59. Curve of stator powers for typical $\mathrm{v}_{\text {wind }}=6 \mathrm{~m} / \mathrm{s}, \mathrm{k}=2, \mathrm{Ng}=17$ and P controller.

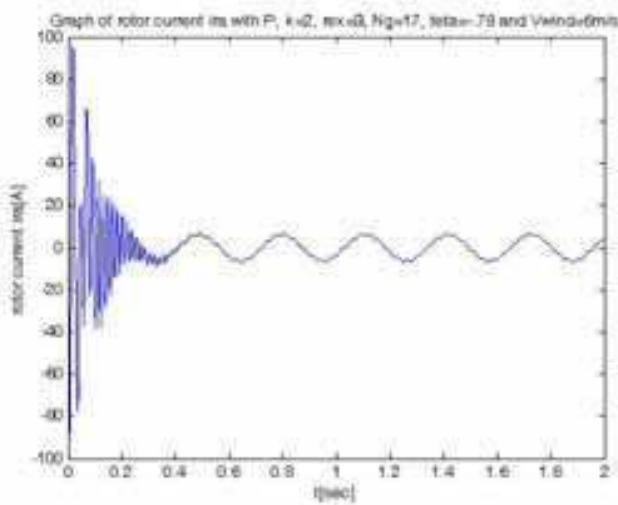

Fig. 60. Curve of rotor current $i_{\text {ra }}$ for typical $v_{\text {wind }}=6 \mathrm{~m} / \mathrm{s}, \mathrm{k}=2, \mathrm{Ng}=17$ and P controller. 


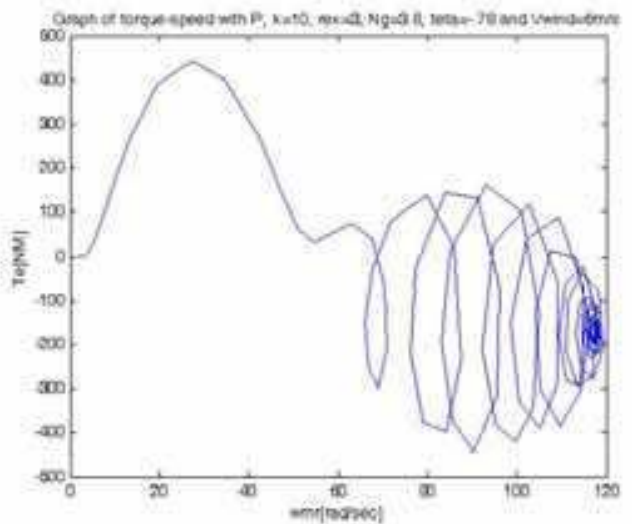

Fig. 61. Curve of torque-speed for typical $\mathrm{v}_{\text {wind }}=6 \mathrm{~m} / \mathrm{s}, \mathrm{k}=10, \mathrm{Ng}=3.8$ and P controller.

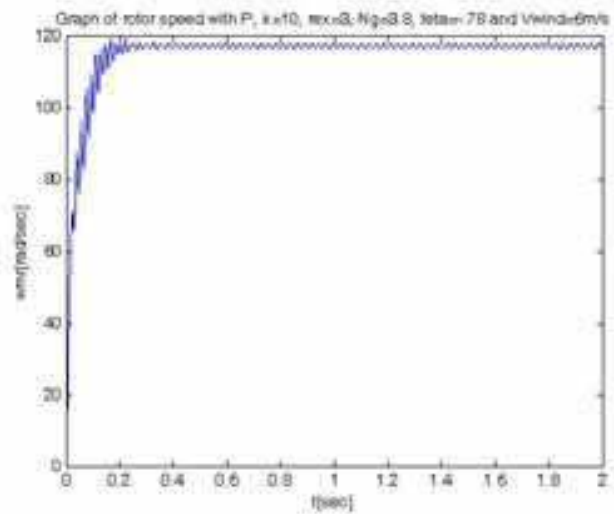

Fig. 62. Curve of rotor speed for typical $\mathrm{v}_{\text {wind }}=6 \mathrm{~m} / \mathrm{s}, \mathrm{k}=10, \mathrm{Ng}=3.8$ and P controller.

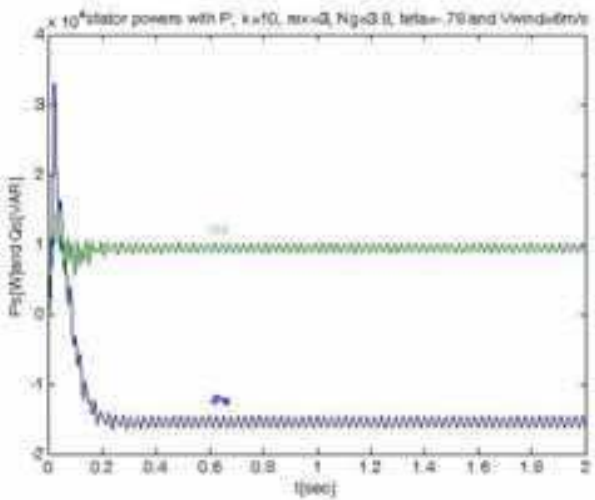

Fig. 63. Curve of stator powers for typical $\mathrm{v}_{\text {wind }}=6 \mathrm{~m} / \mathrm{s}, \mathrm{k}=10, \mathrm{Ng}=3.8$ and P controller. 


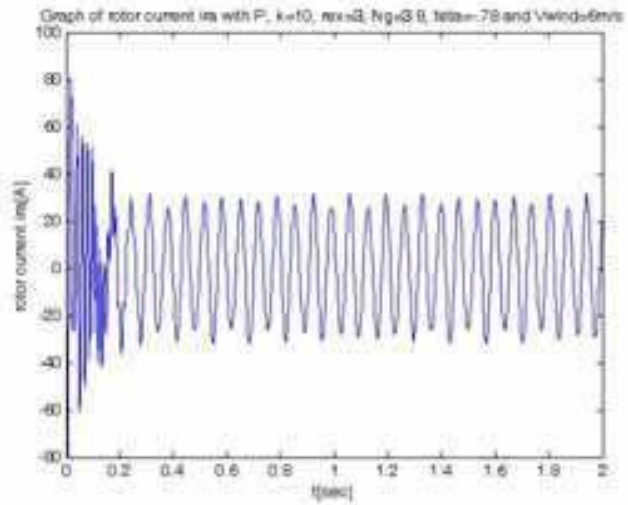

Fig. 64. Curve of rotor current $i_{r a}$ for typical $v_{\text {wind }}=6 \mathrm{~m} / \mathrm{s}, \mathrm{k}=10, \mathrm{Ng}=3.8$ and P controller.

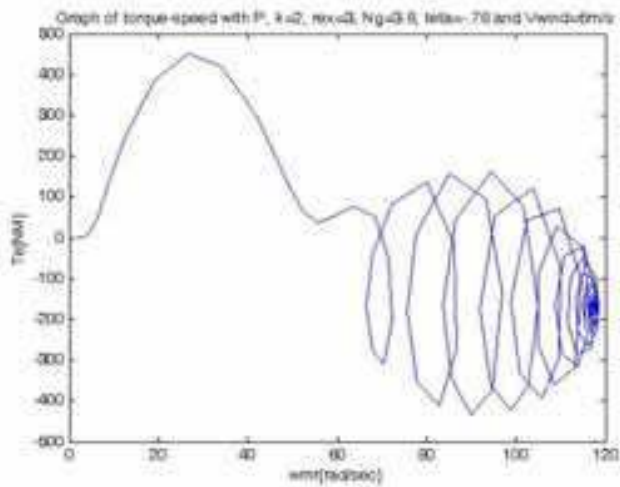

Fig. 65. Curve of torque-speed for typical $\mathrm{v}_{\text {wind }}=6 \mathrm{~m} / \mathrm{s}, \mathrm{k}=2, \mathrm{Ng}=3.8$ and $\mathrm{P}$ controller.

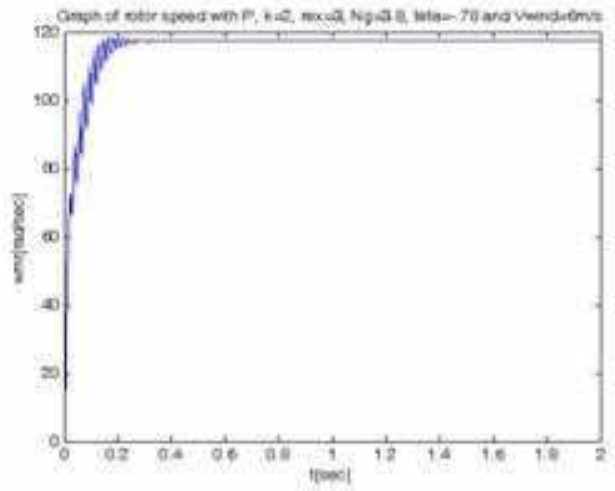

Fig. 66. Curve of rotor speed for typical $\mathrm{v}_{\text {wind }}=6 \mathrm{~m} / \mathrm{s}, \mathrm{k}=2, \mathrm{Ng}=3.8$ and P controller. 


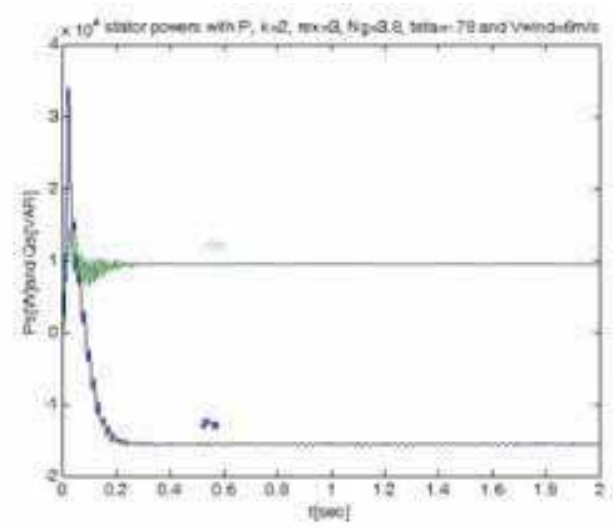

Fig. 67. Curve of stator powers for typical $\mathrm{v}_{\text {wind }}=6 \mathrm{~m} / \mathrm{s}, \mathrm{k}=2, \mathrm{Ng}=3.8$ and P controller.

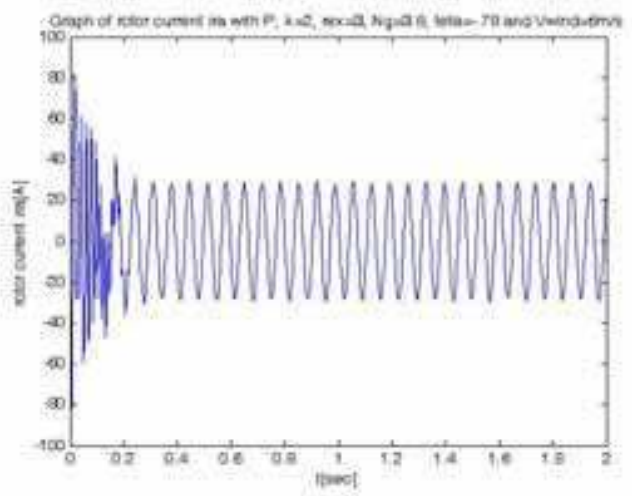

Fig. 68. Curve of rotor current $\mathrm{i}_{\mathrm{ra}}$ for typical $\mathrm{v}_{\text {wind }}=6 \mathrm{~m} / \mathrm{s}, \mathrm{k} 1=2, \mathrm{Ng}=3.8$ and P controller.

\section{Conclusion}

As in this chapter a maximum power wind turbine is modeled with doubly fed induction machine and two P and PI controllers are designed to control stator active and reactive powers of simulated machine, according to the results, it can be concluded that:

1. Sensitivity of $\mathrm{Q}$ to $\mathrm{K}$ is more than sensitivity of $\mathrm{P}$ (especially in that of rotor).

2. The simulated doubly-fed induction machine with improved wind turbine, in generator mode, gives active power to the grid and takes reactive power from it.

3. In this system, gear ratio differs for different speeds and this variation is obvious especially in high speeds as adapting of turbine speed to induction generator speed in high speeds is more difficult.

4. By increasing $r_{e x}$, slope of torque-speed curve rises and speed of induction machine increases.

5. Sensitivity of $P, Q$ and $\omega_{\mathrm{mr}}$ to $\theta$ is very low.

6. Sensitivity of $\omega_{\mathrm{mr}}$ to $\mathrm{k}$ is low and increasing of $\mathrm{k}$, raises swing of $\omega_{\mathrm{mr}}$.

7. In a set point, with increasing $\mathrm{k}$, machine losses declines. 
8. PI voltage and P combinational self tuning controllers can both automatically control the system when rotor external voltage source domain of system drops down.

9. In a PI self tuning voltage controller, Stator active and reactive powers are controlled with the phase and amplitude of rotor external voltage but in $\mathrm{P}$ self tuning combinational controller those are also controlled by pitch angle and torque compensation whereas maximum turbine torque and power can be achieved anyway.

10. In PI self tuning voltage controller $p$ parameter is tuned proportionally with the amplitude of modeled external rotor voltage but in $\mathrm{P}$ self tuning combinational controller proportional parameters are constant.

11. According to output curves, output responses of $P$ self tuning controller are better with lower swing in comparison to PI self tuning output results.

12. A PI voltage controller is more economic for a new wind power plant.

13. A P combinational controller is suitable for wind power plants with pitch angle controller especially with power delivery more than $3000[\mathrm{w}]$ which are promoted.

14. P controller can control the stator active and reactive powers with decreasing swings of them; however, PI controller controls the stator active and reactive powers without any change in them.

15. Simulated doubly fed induction generator delivers active power to the network grid and takes reactive power from it.

\section{References}

Blaabjerg, F. \& Chen, Z., (2006). Power electronics for modern wind turbine, Proceedings of 1598290320, ISBN1598290339, Morgan \& Claypool, Aalborg

Burter, T. \& Bossanyi, E. \& Jenkins N. \& Sharpe, D. (2001). Wind energy handbook, John Wiley and sons

Ehernberg, J. \& Andersen B. \& Rebsdorf A., (2001). Windkraf tan lagen fur den megawattbereich, Digitale steuerungeines dopplet gespei sten asynchron generators ohne lagegeber, Magazine Electronik, Issue 19, page numbers(78-87)

Hosseinpur, M. \& Yazdiyan, A. \& Mohamadiyan, M. (2001). Maximum power control of wind system, variable speed connected to grid using matrix converter. ICEE Transaction

Kojooyan Jafari H. \& Radan, A. (2008). Open loop control of doubly fed machine with improved wind turbine, Proceedings of $6^{\text {th }}$ WSEAS conference on environment, ecosystems and development, page numbers (22-27), WSEAS, ISBN978-960-474-045-1, Cairo, Egypt

Kojooyan Jafari H. \& Radan, A. (2009). Open loop control of doubly fed machine with improved wind turbine, WSEAS Transaction on circuit and systems, Vol.8, No.2 (Feb.2009) page numbers (217-226), WSEAS, ISSN1109-2734

Kojooyan Jafari H. \& Radan, A. (2010). Comparison between Self Tuning PI Voltage Control of DFIG and a Combinational Control for Improved Wind Turbines, IREACO International Control, (Sep.2010), IREACO Journal of Praise Worthy Prize, ISSN19746059 , Cd-Rom ISSN1974-6067

Krause, P.C., (1986). Analysis of electrical machinery, McGraw-Hill Inc 


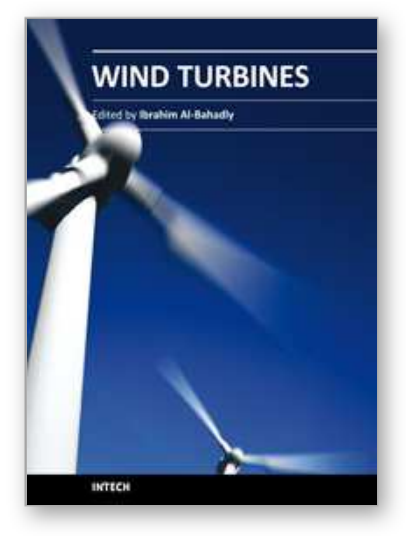

\author{
Wind Turbines \\ Edited by Dr. Ibrahim Al-Bahadly
}

ISBN 978-953-307-221-0

Hard cover, 652 pages

Publisher InTech

Published online 04, April, 2011

Published in print edition April, 2011

The area of wind energy is a rapidly evolving field and an intensive research and development has taken place in the last few years. Therefore, this book aims to provide an up-to-date comprehensive overview of the current status in the field to the research community. The research works presented in this book are divided into three main groups. The first group deals with the different types and design of the wind mills aiming for efficient, reliable and cost effective solutions. The second group deals with works tackling the use of different types of generators for wind energy. The third group is focusing on improvement in the area of control. Each chapter of the book offers detailed information on the related area of its research with the main objectives of the works carried out as well as providing a comprehensive list of references which should provide a rich platform of research to the field.

\title{
How to reference
}

In order to correctly reference this scholarly work, feel free to copy and paste the following:

Hengameh Kojooyan Jafari and Ahmed Radan (2011). Wind Turbine Model and Maximum Power Tracking Strategy, Wind Turbines, Dr. Ibrahim Al-Bahadly (Ed.), ISBN: 978-953-307-221-0, InTech, Available from: http://www.intechopen.com/books/wind-turbines/wind-turbine-model-and-maximum-power-tracking-strategy

\section{INTECH}

open science | open minds

\section{InTech Europe}

University Campus STeP Ri

Slavka Krautzeka 83/A

51000 Rijeka, Croatia

Phone: +385 (51) 770447

Fax: +385 (51) 686166

www.intechopen.com

\section{InTech China}

Unit 405, Office Block, Hotel Equatorial Shanghai

No.65, Yan An Road (West), Shanghai, 200040, China 中国上海市延安西路65号上海国际贵都大饭店办公楼 405 单元

Phone: +86-21-62489820

Fax: +86-21-62489821 
(C) 2011 The Author(s). Licensee IntechOpen. This chapter is distributed under the terms of the Creative Commons Attribution-NonCommercialShareAlike-3.0 License, which permits use, distribution and reproduction for non-commercial purposes, provided the original is properly cited and derivative works building on this content are distributed under the same license. 